\title{
Supporting Information of
}

\section{Synthesis, Structural, Spectral, and Photoswitchable Properties of cis- and trans-2, 2, 2', 2'-Tetramethyl-1, 1'-indanylindanes}

\author{
Toshiaki Shimasaki, ${ }^{\dagger+}$ Shin-ichiro Kato ${ }^{\dagger *}$ and Teruo Shinmyozu *, \\ ${ }^{\dagger}$ Institute for Materials Chemistry and Engineering (IMCE) and ${ }^{\ddagger}$ Department of Molecular Chemistry, \\ Graduate School of Sciences, Kyushu University, Hakozaki 6-10-1, Higashi-ku, Fukuoka 812-8581, Japan
}

\section{Contents}

1. General experimental methods (S4).

2. Experimental (S4-S6)

3. DFT-optimized structural properties of trans-1 and 2 as well as trans- and cis-10 (S6).

4. X-ray Crystallographic structural analysis (S7-S8).

TABLE S1. Crystal data and structural refinement for trans-1, 2 and cis-1,2 (S8).

TABLE S2. Crystal data and structural refinement for trans-8 and 9 (S9).

FIGURE S1. X-ray crystal structure of trans-2 (S9).

FIGURE S2. X-ray crystal structure of trans-1(S10).

FIGURE S3. Parameters of $>A-B$ for 1 and 2 (S10).

FIGURE S4. X-ray crystal structure of cis-1 and 2 (S10).

FIGURE S5. X-ray crystal structure of trans-8(S11).

FIGURE S6. Top view of crystal packing of trans-8 (S11).

FIGURE S7. Side view of crystal packing of trans-8 (S11).

FIGURE S8. X-ray crystal structure of trans-9(S12).

FIGURE S9. Crystal packing of trans-9 (S12).

FIGURE S10. Crystal packing of trans-1 (S12).

FIGURE S11. Top view of crystal packing of trans-2 (S13).

FIGURE S12. Front view of crystal packing of trans-2 (S13). 
FIGURE S13. Front view of crystal packing of cis-1 (S14).

FIGURE S14. Front view of crystal packing of cis-2 (S14).

TABLE S3. X-ray and calculated structural data of cis- and trans-indanylindanes (S14).

\section{NMR spectra.}

FIGURE S15. $\quad{ }^{1} \mathrm{H}$ NMR spectrum of trans-1 (300 MHz) (S15).

FIGURE S16 ${ }^{13} \mathrm{C}$ NMR spectrum of trans-1 (75 MHz) (S15).

FIGURE S17. $\quad{ }^{1} \mathrm{H}$ NMR spectrum of cis-1 (300 MHz) (S16).

FIGURE S18. $\quad{ }^{13} \mathrm{C}$ NMR spectrum of cis-1 (75 MHz) (S16).

FIGURE S19. $\quad{ }^{1} \mathrm{H}$ NMR spectrum of trans-2 (300 MHz) (S17).

FIGURE S20. $\quad{ }^{13} \mathrm{C}$ NMR spectrum of trans-2 (75 MHz) (S17).

FIGURE S21. $\quad{ }^{1} \mathrm{H}$ NMR spectrum of cis-2 (300 MHz) (S18).

FIGURE S22. $\quad{ }^{13} \mathrm{C}$ NMR spectrum of cis-2 (75 MHz) (S18).

FIGURE S23. $\quad{ }^{1} \mathrm{H}$ NMR spectrum of trans-8 (300 MHz) (S19).

FIGURE S24. $\quad{ }^{13} \mathrm{C}$ NMR spectrum of trans-8 (75 MHz) (S19).

FIGURE S25. $\quad{ }^{1} \mathrm{H}$ NMR spectrum of trans-9 (300 MHz) (S20).

FIGURE S26. $\quad{ }^{13} \mathrm{C}$ NMR spectrum of trans-9 (75 MHz) (S20).

FIGURE S27. $\quad{ }^{1} \mathrm{H}$ NMR spectrum of mixture of trans-10 and cis-10 (300 MHz) (S21).

FIGURE S28. $\quad{ }^{13} \mathrm{C}$ NMR spectrum of mixture of trans-10 and cis-10 (75 MHz) (S21).

\section{Comparison of rate of photoisomerization between 1 and azobenzene}

FIGURE S29. Comparison of rate of trans to cis photo-isomerization between $\mathbf{1}$ and azobenzene (S22).

FIGURE S30. Comparison of rate of cis to trans photo-isomerization between $\mathbf{1}$ and azobenzene (S22).

FIGURE S31 Repetitive switching experiments between trans-1 and cis-1 at $23{ }^{\circ} \mathrm{C}$ (S23).

\section{Theoretical calculations.}

TABLE S4. Coordinate of the trans-thiirane 6 at the B3LYP / 6-31G* level of theory (S23-S24).

TABLE S5. Coordinate of the cis-thiirane 6 at the B3LYP / 6-31G* level of theory (S24-S25). 
TABLE S6. Coordinate of the trans-1 at the B3LYP / 6-31G* level of theory (S25-S27).

TABLE S7. Coordinate of the cis-1 at the B3LYP / 6-31G* level of theory (S27-S28).

TABLE S8. Coordinate of the trans-2 at the B3LYP / 6-31G* level of theory (S28-S29).

TABLE S9. Coordinate of the cis-2 at the B3LYP / 6-31G* level of theory (S29-S30).

TABLE S10. Coordinate of the trans-8 at the B3LYP / 6-31G* level of theory (S30-S31).

TABLE S11. Coordinate of the trans-9 at the B3LYP / 6-31G* level of theory (S31-S33).

TABLE S12. Coordinate of the trans-10 at the B3LYP / 6-31G (2d) level of theory (S33-S35).

FIGURE S32. Optimized structures of trans-6 and cis-6 at the B3LYP / 6-31G* level of theory (S35).

FIGURE S33. Optimized structure of trans-8 at the B3LYP / 6-31G* level of theory (S36).

FIGURE S34. Optimized structure of trans-9 at the B3LYP / 6-31G* level of theory (S36).

FIGURE S35. Optimized structure of trans-10 at the B3LYP / 6-31G (2d) level of theory (S36).

FIGURE S36. Frontier orbitals of the optimized trans-1 and 2 at B3LYP / 6-311G** level of theory (S37).

FIGURE S37. Frontier orbitals of the optimized cis-1 and 2 at B3LYP / 6-311G** level of theory (S37).

FIGURE S358 MO levels (eV) obtained by the DFT// B3LYP 6-311+G** level calculations. Energy transitions and the oscillator strengths for the most important HOMO-LUMO bands (S38).

FIGURE S39. Calculated oscillator strengths of trans-1, trans-2, cis-1 and cis-2 at TDDFT//B3LYP/ 6-31G* level of theory (S38).

FIGURE S40. Electronic spectra of trans-1 (a, absorption: black, fluorescence: blue, $\left.\lambda_{\mathrm{ex}} 315 \mathrm{~nm}\right)$, trans-2(b, absorption: black, fluorescence: blue, $\lambda_{\text {ex }} 336 \mathrm{~nm}$ ), cis-1 (c, absorption: black, emission: blue, $\lambda_{\text {ex }}$ $341 \mathrm{~nm}$ ), and cis-2 (d, absorption: black, emission: blue, $\lambda_{\mathrm{ex}} / 354 \mathrm{~nm}$ ) at $1 \times 10^{-5} \mathrm{~mol} / \mathrm{L}$ in $\mathrm{CH}_{3} \mathrm{CN}$ at $23^{\circ} \mathrm{C}(\mathrm{S} 39)$.

TABLE S13. UV-vis and fluorescent data of stiff-stilbenes in $\mathrm{CH}_{3} \mathrm{CN}$ at $23^{\circ} \mathrm{C}(\mathrm{S} 39)$.

TABLE S14. Selected data of UV calculations by TDDFT method at B3LYP/ 6-31G* for trans-1 (S40).

TABLE S15. Selected data of UV calculations by TDDFT method at B3LYP/ 6-31G* for cis-1 (S40).

TABLE S16. Selected data of UV calculations by TDDFT method at B3LYP / 6-31G* for trans-2(S40).

TABLE S17. Selected data of UV calculations by TDDFT method at B3LYP/ 6-31G* for cis-2 (S41).

8. Reference (S41-S42). 


\section{General experimental methods.}

Melting points are uncollected. IR spectra were measured as $\mathrm{KBr}$ pellets or neat on $\mathrm{NaCl}$ disks. $\mathrm{UV} / \mathrm{Vis}$ and fluorescence spectra were measured in a $10 \mathrm{~mm}$ width quartz cell. ${ }^{1} \mathrm{H}$ NMR spectra were determind in $\mathrm{CDCl}_{3}$ unless otherwise noted. Chemical shifts $(\delta)$ are given as $\delta$ values (ppm) relative to tetramethylsilane (TMS). The coupling constants $(J)$ are given in hertz. FAB-MS spectra were recorded with $m$-nitrobenzyl alcohol as a matrix. THF was distilled from sodium and benzophenone under an argon atmosphere just before use. $\mathrm{CH}_{3} \mathrm{CN}$ (for the spectral measurement) was deoxygenated under ultrasound irradiation for $10 \mathrm{~min}$ just before use.

\section{Experimental}

trans-2, 2, 14, 14-Tetramethyl-5, 17-dimethyl-1, 13-indanylindane (trans-8). A THF solution (10 mL) of the trans-2 (56.1 mg, $0.13 \mathrm{mmol}$ ) was cooled to $-78^{\circ} \mathrm{C}$ under $\mathrm{Ar}$ atmosphere, and the $1.54 \mathrm{M}$-hexane solution of $n-\mathrm{BuLi}(0.20 \mathrm{~mL}, 0.28 \mathrm{mmol})$ was added slowly from a syringe to this mixture. After stirring for $30 \mathrm{~min}$ at $-78{ }^{\circ} \mathrm{C}$, methyl iodide $(0.15 \mathrm{~mL}, 1.30 \mathrm{mmol})$ was added in one portion to the mixture, and the reaction mixture was allowed to warm to room temperature and stirred at room temperature for $15 \mathrm{hr}$. The reaction mixture was quenched with $\mathrm{H}_{2} \mathrm{O}$, and extracted with $\mathrm{CH}_{2} \mathrm{Cl}_{2}$. The combined $\mathrm{CH}_{2} \mathrm{Cl}_{2}$ extracts were washed with water, dried over $\mathrm{MgSO}_{4}$, filtered, and the filtrate was evaporated under reduced pressure to give the crude product, which was purified by column chromatography on silica gel with hexane, followed by recrystallization from hexane to give trans-8 (31.8 mg, 80\%) as colorless crystal: mp $136-137{ }^{\circ} \mathrm{C} ;{ }^{1} \mathrm{H} \mathrm{NMR}\left(300 \mathrm{MHz}, \mathrm{CDCl}_{3}\right) \delta$ $1.31\left(12 \mathrm{H}, \mathrm{s},-\mathrm{CH}_{3}\right), 2.34\left(6 \mathrm{H}, \mathrm{s}, \mathrm{Ar}-\mathrm{CH}_{3}\right), 2.72(4 \mathrm{H}, \mathrm{s}$, benzyl-H$), 6.93(2 \mathrm{H}, \mathrm{d}, \mathrm{J}=8.1 \mathrm{~Hz}, \mathrm{Ar}-\mathrm{H}), 6.94(2 \mathrm{H}, \mathrm{s}$, Ar-H), 7.37 (2H, d, J= 7.8 Hz, Ar-H); ${ }^{13} \mathrm{C}$ NMR (75 MHz, $\left.\mathrm{CDCl}_{3}\right) \delta 21.4$ (-Me), 27.6 (Ar-Me), 50.4, 51.9, 124.9, 125.6, 127.6, 136.7, 140.1, 144.9, 145.3; HMRS (FAB) m/z calcd for $\mathrm{C}_{24} \mathrm{H}_{28} 316.2191$ [M $\mathrm{M}^{+}$, found: 316.2167. Anal. Calcd for $\mathrm{C}_{24} \mathrm{H}_{28} \cdot 0.2 \mathrm{H}_{2} \mathrm{O}: \mathrm{C}, 90.09 ; \mathrm{H}, 8.82$. Found C, 90.06; H, 8.94.

trans-2, 2, 23, 23-Tetramethyl-5, 26-bis-(1-naphthyl)-1, 22-indanylindane (trans-9). To a mixture of trans-2 (21.0 mg, $47.1 \mu \mathrm{mol})$, toluene $(10 \mathrm{~mL})$, and saturated aqueous $\mathrm{Na}_{2} \mathrm{CO}_{3}$ solution $(3 \mathrm{~mL})$ was added 1-naphthylboronic acid (16.2 mg, $94.4 \mu \mathrm{mol})$, and the mixture was deoxygened with Ar bubbling. After 10 min, $\mathrm{Pd}\left(\mathrm{PPh}_{3}\right)_{4}(10.9 \mathrm{mg}, 9.42 \mu \mathrm{mol})$ was added to the mixture and the mixture was refluxed for $3 \mathrm{hr}$. The cooled reaction mixture was washed with brine, dried over $\mathrm{MgSO}_{4}$, and filtered. The filtrate was concentrated 
under reduced pressure and the concentrate was purified by column chromatography on silica gel with $\mathrm{CH}_{2} \mathrm{Cl}_{2}$ / hexane (1 / 10), followed by recrystallization from $\mathrm{CH}_{2} \mathrm{Cl}_{2}$ / hexane to give trans-9 (22.4 $\left.\mathrm{mg}, 88 \%\right)$ as slightly yellow crystals. trans-9: mp $223-224{ }^{\circ} \mathrm{C} ; \quad{ }^{1} \mathrm{H}$ NMR $\left(300 \mathrm{MHz}, \mathrm{CDCl}_{3}\right) \delta 1.49\left(12 \mathrm{H}, \mathrm{s},-\mathrm{CH}_{3}\right), 2.91(4 \mathrm{H}, \mathrm{s}$, benzyl- $\left.H_{2}\right), 7.31(2 \mathrm{H}, \mathrm{d}, J=7.9 \mathrm{~Hz}, \mathrm{Ar}), 7.35$ (2H, s, Ar), 7.46-7.55 (8H, m, Ar), 7.67 (2H, d, J = 7.9 Hz, Ar), $7.86(2 \mathrm{H}, \mathrm{d}, J=7.7 \mathrm{~Hz}), 7.92(2 \mathrm{H}, \mathrm{d}, J=8.1 \mathrm{~Hz}), 8.05(2 \mathrm{H}, \mathrm{d}, J=7.3 \mathrm{~Hz}) ;{ }^{13} \mathrm{C} \mathrm{NMR}\left(75 \mathrm{MHz}, \mathrm{CDCl}_{3}\right) \delta 28.2$, 51.2, 52.5, 125.8, 126.1, 126.3, 126.4, 126.6, 127.31, 127.34, 127.9, 128.1, 128.7, 132.1, 134.3, 139.9, 140.9, 142.2, 145.8, 146.4; HMRS (FAB) $\left[\mathrm{M}^{+}\right] \mathrm{m} / \mathrm{z}$ calcd for $\mathrm{C}_{42} \mathrm{H}_{36}$ 540.2817, found 540.2830. Anal. Calcd for $\mathrm{C}_{42} \mathrm{H}_{36} 0.3 \mathrm{H}_{2} \mathrm{O}$ : C, 92.37; H, 6.75. Found C, 92.34; H, 6.75 .

trans-9 was alternatively synthesized by the Suzuki-Miyaura coupling between the bromo-indanone 3 and 1-naphthyl boronic acid (67\%), followed by the McMurry coupling (48\%). This route (2 steps, 32\% from 3) is more suitable for the introduction of $\mathrm{sp}^{2}$-carbons at the 5, 5'-positions of the stiff-stilbene than the route reported in Scheme 3 (4 steps, 20\% from 3).

trans-2, 2, 18, 18-Tetramethyl-5, 21-bis-(1-trimethylsilyl)-1, 17-indanylindane (trans-10). To a deoxygened mixture of the pure-trans-2 $(50.0 \mathrm{mg}, 112.2 \mu \mathrm{mol})$ and triethylamine $(15 \mathrm{~mL})$ by Ar bubbling for $10 \mathrm{~min}$, were added successively trimethylsilylacetylene (89.1 mg, $907 \mu \mathrm{mol}), \mathrm{Pd}\left(\mathrm{PPh}_{3}\right)_{4}(25.9 \mathrm{mg}, 22.4 \mu \mathrm{mol})$, and CuI (2.13 $\mathrm{mg}, 11.2 \mu \mathrm{mol}$ ) and the mixture was heated at $100{ }^{\circ} \mathrm{C}$ for $12 \mathrm{hr}$. The cooled reaction mixture was concentrated under reduced pressure, and the concentrate was purified by column chromatography on silica gel with hexane to give a mixture of the trans- and cis-10 (74 / 26) (45.4 mg, 84\%) as yellow slurry, which could not be separated because of high solubility to non-polar solvent such as hexane. The formation of the trans-10 was confirmed by the high resolution mass, IR, ${ }^{1} \mathrm{H}$ NMR (benzyl moiety), and ${ }^{13} \mathrm{C}$ NMR (ethynyl) spectra. trans-10: ${ }^{1} \mathrm{H}$ NMR $\left(300 \mathrm{MHz}, \mathrm{CDCl}_{3}\right) \delta 0.22\left(18 \mathrm{H}, \mathrm{s}, \mathrm{Si}-\mathrm{CH}_{3}\right), 1.22\left(12 \mathrm{H}, \mathrm{s},-\mathrm{CH}_{3}\right), 2.69\left(4 \mathrm{H}, \mathrm{s}\right.$, benzyl- $\left.\mathrm{H}_{2}\right)$, $7.22(2 \mathrm{H}, \mathrm{d}, J=7.4 \mathrm{~Hz}, \mathrm{Ar}), 7.26(2 \mathrm{H}, \mathrm{s}, \mathrm{Ar}), 7.35(2 \mathrm{H}, \mathrm{d}, J=7.4 \mathrm{~Hz}, \mathrm{Ar}) ;{ }^{13} \mathrm{C}$ NMR $\left(75 \mathrm{MHz}, \mathrm{CDCl}_{3}\right) \delta 94.5$ (TMS- $C \equiv C$ ), $105.7\left(\mathrm{C} \equiv C\right.$-Ar); $\quad$ HMRS (FAB) $\mathrm{m} / \mathrm{z}$ calcd. for $\mathrm{C}_{32} \mathrm{H}_{40} \mathrm{Si}_{2} 480.2669\left[\mathrm{M}^{+}\right]$, found 480.2693 .

Photoisomerization experiments. The benzene solution of trans $-\mathbf{1}^{1}$ was deoxygenated with Ar bubbling for $5 \mathrm{~min}$ in a quarz sample tube. The trans to cis isomerization was carried out by irradiation with sterilizing lamps $(10 \mathrm{~W} \times 7, \lambda=254 \mathrm{~nm})$ at $23{ }^{\circ} \mathrm{C}$, and the reaction was monitored by the ${ }^{1} \mathrm{H}$ NMR spectra $(10,20,40$, and 60 min). The cis-to-trans isomerization process was performed by irradiating the benzene solution of the cis-isomer with an ultra-high-pressure $\mathrm{Hg} \operatorname{lamp}(\lambda=$ ca. $380 \mathrm{~nm})$ at $23{ }^{\circ} \mathrm{C}$ and the reaction was monitored the 
reaction by the ${ }^{1} \mathrm{H}$ NMR spectra $(10,20$, and $30 \mathrm{~min})$.

Theoretical methods. All calculations were performed using the Gaussian $03^{2}$ suite of programs. All of the optimized structure, frequency, and time-dependent calculations were performed using the Becke's three-parameter hybrid functional (B3) ${ }^{3}$ with the correlation functional of Lee, Yang, and Parr (LYP), ${ }^{4,5}$ and the basis sets 6-31G*, and single-point energy calculations were performed at B3LYP / 6-311+G**. The structural optimization and potential energy curves were performed as a function of the central C8-C1-C12-C19 dihedral angle at the B3LYP / 6-31G* and B3LYP / 6-311+G** level, respectively. Restricted calculations were performed, as all relevant species were closed shell molecules.

\section{DFT-optimized structural properties of trans-1 and 2 as well as trans- and cis-10.}

The structural optimizations of trans-1 and 2 were carried out at the DFT // B3LYP/ 6-31G* level of theory, and the predicted structural parameters were compared to those of the observed ones (Table S3). The calculated $\mathrm{C}=\mathrm{C}$ bonds of trans-1 and $\mathbf{2}$ were slightly longer than the corresponding observed ones. The calculated dihedral angle of trans-1 was comparable to the observed ones, whereas that of trans- 2 was slightly larger than that of the observed values $(0.007-0.01$ A). Although the difference between the observed and calculated angles defined by $>\mathrm{A}-\mathrm{B}$ of trans- 2 was only $0.2^{\circ}$, it was more than $3^{\circ}$ in trans-1. The difference between the observed and calculated structural parameters was probably due to crystal packing forces. The energy differences based on this level of theory between trans-1 and cis-1, as well as trans-2 and cis-2, were 1.30 and $1.32 \mathrm{kcal} / \mathrm{mol}$, respectively.

We could not separate the trans- and cis-isomers of $\mathbf{1 0}$ because of similar chromatographic mobilities. In the B3LYP/6-31G (2d) optimized structure of trans-10 with an almost $C_{2}$ symmetry (Figure S32), the bond length of the $\mathrm{C}=\mathrm{C}$ bond $(\mathrm{C} 1-\mathrm{C} 17)$ and dihedral angle around the $\mathrm{C}=\mathrm{C}$ bond $(\mathrm{C} 8-\mathrm{C} 1-\mathrm{C} 17-\mathrm{C} 24)$ were expected to be $1.363 \AA$ and $-167.1^{\circ}$, respectively, and these values were comparable to those of trans-8 and $\mathbf{9}$ (Table S3). 


\section{X-ray crystallographic structure analysis.}

X-ray crystallography was performed on a Rigaku RAXIS RAPID imaging plate diffractometer with graphite monochromated Mo K $\alpha$ radiation $(\lambda=0.71070 \AA)$. The data were collected at $113 \mathrm{~K}$ using $\omega$ scan in the $\theta$ range of 2.2-27.6 deg. The structures of trans-1, 2 and cis-1 were solved by direct method (SIR 97) and were refined using full-matrix least squares (teXsan for all compounds) based on $F^{2}$ of all independent reflections measured. The structure of cis-2 was solved using the SHELXL97 program. ${ }^{6}$ All H atoms were located at ideal positions and refined as riding on their parent atoms with $U_{\text {iso }}(\mathrm{H})=1.2-1.5 U_{\text {eq }}(\mathrm{C})$ and with $\mathrm{C}-\mathrm{H}=1.10 \AA$ for trans-1 and cis-1, and $0.95 \AA$ for trans-2, cis-2, trans-8 and trans-9.

Crystal data for trans-1 (CCDC 625980): $\mathrm{C}_{22} \mathrm{H}_{24}, M=288.43$, colorless prism, triclinic, space group $P-1$ (\#2), $a=10.1622$ (3) $\AA, b=11.5565$ (4) $\AA, c=16.7153$ (7) $\AA, \alpha=70.356$ (1), $\beta=73.339$ (1), $\gamma=64.827(2)^{\circ}, V=$ $1649.3(1) \AA^{3}, T=123 \mathrm{~K}, Z=2, D_{\mathrm{c}}=1.350 \mathrm{~g} \mathrm{~cm}^{-1}, F(000)=624, \mu=0.65 \mathrm{~cm}^{-1}$, crystal dimensions $0.39 \times$ $0.35 \times 0.10 \mathrm{~mm}^{3}, 15472$ reflections collected, 7444 unique $\left(R_{\mathrm{int}}=0.045\right)$ which were used in all calculations. $R_{1}=0.054$ for $I>2 \sigma(I), R=0.085, w R_{2}=0.153, S=1.87$ for all data.

Crystal data for cis-1 (CCDC 625981): $\mathrm{C}_{22} \mathrm{H}_{22}, M=288.43$, colorless prism, triclinic, space group $P-1$ (\#2), $a$ $=8.4851$ (3) $\AA, b=8.6692$ (5) $\AA, c=11.7774$ (5) $\AA, \alpha=103.661$ (2), $\beta=98.748$ (2), $\gamma=99.811(4)^{\circ}, V=$ $812.61(7) \AA^{3}, T=113 \mathrm{~K}, Z=2, D_{\mathrm{c}}=1.179 \mathrm{~g} \mathrm{~cm}^{-1}, F(000)=1280, \mu=0.66 \mathrm{~cm}^{-1}$, crystal dimensions $0.70 \times$ $0.56 \times 0.48 \mathrm{~mm}^{3}, 6968$ reflections collected, 3581 unique $\left(R_{\text {int }}=0.045\right)$ which were used in all calculations. $R_{1}$ $=0.058$ for $I>2 \sigma(I), R=0.096, w R_{2}=0.172, S=2.54$ for all data.

Crystal data for trans-2 (CCDC 625982): $\mathrm{C}_{22} \mathrm{H}_{22} \mathrm{Br}_{2}, M=446.22$, colorless prism, triclinic, space group $P-1$ (\#2), $a=9.9768$ (2) $\AA, b=11.5045$ (3) $\AA, c=18.2991$ (5) $\AA, \alpha=80.1604(8)^{\circ}, \beta=76.659(2)^{\mathrm{o}}, \gamma=67.7642(4)^{\circ}$, $V=1883.52(8) \AA^{3}, T=113 K, Z=4, D_{\mathrm{c}}=1.573 \mathrm{~g} \mathrm{~cm}^{-1}, F(000)=896, \mu=43.2 \mathrm{~cm}^{-1}$, crystal dimensions 0.27 $\times 0.14 \times 0.10 \mathrm{~mm}^{3}, 17294$ reflections collected, 8433 unique $\left(R_{\text {int }}=0.034\right)$ which were used in all calculations. $R_{1}=0.038$ for $I>2 \sigma(I), R=0.061, w R_{2}=0.105, S=1.11$ for all data.

Crystal data for cis-2 (CCDC 625983): $\mathrm{C}_{22} \mathrm{H}_{22} \mathrm{Br}_{2}, M=446.22$, colorless prism, triclinic, space group $P-1$ (\#2), $a=8.5923$ (4) $\AA, b=11.3461(5) \AA, c=11.8836(7) \AA, \alpha=104.926(2)^{\circ}, \beta=108.693(2)^{\circ}, \gamma=110.087(1)^{\circ}, V$ $=938.53(9) \AA^{3}, T=113 K, Z=2, D_{c}=1.579 \mathrm{~g} \mathrm{~cm}^{-1}, F(000)=448, \mu=43.3 \mathrm{~cm}^{-1}$, crystal dimensions $0.69 \times$ $0.62 \times 0.47 \mathrm{~mm}^{3}, 8534$ reflections collected, 4209 unique $\left(R_{\text {int }}=0.041\right)$ which were used in all calculations. $R_{1}$ $=0.037$ for $I>2 \sigma(I), R=0.072, w R_{2}=0.099, S=1.41$ for all data.

Crystal data for trans-8 (CCDC 629939): $\mathrm{C}_{24} \mathrm{H}_{28}, M=326.48$, colorless prism, triclinic, space group $P-1$ (\#2), 
$a=9.5186(3) \AA, b=12.2793$ (4) $\AA, c=16.6625(10) \AA, \alpha=98.6777$ (15), $\beta=97.2329(11), \gamma=102.8273$

${ }^{\circ}, V=1851.35(11) \AA^{3}, T=113 K, Z=4, D_{\mathrm{c}}=1.497 \mathrm{~g} \mathrm{~cm}^{-1}, F(000)=1088, \mu=0.077 \mathrm{~cm}^{-1}$, crystal dimensions $0.56 \times 0.50 \times 0.20 \mathrm{~mm}^{3}, 16558$ reflections collected, 6329 unique $\left(R_{\mathrm{int}}=0.065\right)$ which were used in all calculations. $\quad R_{1}=0.051$ for $I>2 \sigma(I), R=0.070, w R_{2}=0.153, S=1.05$ for all data.

Crystal data for trans -9 (CCDC 629940): $\mathrm{C}_{42} \mathrm{H}_{36}, M=540.74$, colorless prism, triclinic, space group $P-1$ (\#2), $a=11.2423(10) \AA, b=11.7930(11) \AA, c=13.3567(10) \AA, \alpha=108.197(2), \beta=105.652(5), \gamma=108.365(2)^{\circ}$, $V=1457.4(2) \AA^{3}, T=113 \mathrm{~K}, Z=2, D_{\mathrm{c}}=1.232 \mathrm{~g} \mathrm{~cm}^{-1}, F(000)=576, \mu=0.069 \mathrm{~cm}^{-1}$, crystal dimensions 0.51 $\times 0.46 \times 0.10 \mathrm{~mm}^{3}, 6032$ reflections collected, 3757 unique $\left(R_{\mathrm{int}}=0.065\right)$ which were used in all calculations. $R_{1}=0.070$ for $I>2 \sigma(I), R=0.116, w R_{2}=0.205, S=1.07$ for all data.

TABLE S1. Crystal data and structural refinement for trans-1,2 and cis-1,2.

\begin{tabular}{|c|c|c|c|c|}
\hline & trans-1 & cis-1 & trans-2 & cis-2 \\
\hline empirical formura & $\mathrm{C} 22 \mathrm{H} 24$ & $\mathrm{C} 22 \mathrm{H} 24$ & $\mathrm{C} 22 \mathrm{H} 22 \mathrm{Br} 2$ & $\mathrm{C} 22 \mathrm{H} 22 \mathrm{Br} 2$ \\
\hline crystal habit, color & prizmatic, colorless & prizmatic, colorless & prizmatic, colorless & prizmatic, colorless \\
\hline$M\left(\mathrm{~g} \mathrm{~mol}^{-1}\right)$ & 288.43 & 288.43 & 446.22 & 446.22 \\
\hline cryst. syst. & $\mathrm{P}-1$ (\#2) & $\mathrm{P}-1(\# 2)$ & $\mathrm{P}-1(\# 2)$ & $\mathrm{P}-1(\# 2)$ \\
\hline space group & triclinic & triclinic & triclinic & triclinic \\
\hline $\mathrm{a}(\AA)$ & $10.1622(3)$ & $8.4851(3)$ & $9.9768(2)$ & $8.5923(4)$ \\
\hline b $(\AA)$ & $11.5565(4)$ & $8.6692(5)$ & $11.5045(3)$ & $11.3461(5)$ \\
\hline$c(\AA)$ & $16.7153(7)$ & $11.7774(5)$ & $18.2991(5)$ & $11.8836(7)$ \\
\hline$\alpha$ (deg.) & $70.356(1)$ & $103.661(2)$ & $80.1604(8)$ & $104.926(2)$ \\
\hline$\beta$ (deg.) & $73.339(1)$ & $98.748(2)$ & $76.6590(2)$ & $108.6930(2)$ \\
\hline$\gamma$ (deg.) & $64.827(2)$ & $99.811(3)$ & $67.7642(4)$ & $110.0870(1)$ \\
\hline$V\left(\AA^{3}\right)$ & $1649.3(1)$ & $812.61(7)$ & $1883.52(8)$ & $938.53(9)$ \\
\hline Z & 4 & 2 & 4 & 2 \\
\hline$D_{\text {calcd }}\left(\mathrm{g} \mathrm{cm}^{-1}\right)$ & 1.162 & 1.179 & 1.573 & 1.579 \\
\hline$\mu(\mathrm{Mo} \mathrm{K} \alpha)\left(\mathrm{mm}^{-1}\right)$ & 0.65 & 0.66 & 43.17 & 43.32 \\
\hline$F(000)$ & 624.00 & 312.00 & 896.00 & 448.00 \\
\hline$T(\mathrm{~K})$ & $-160^{\circ} \mathrm{C}$ & $-160^{\circ} \mathrm{C}$ & $-160^{\circ} \mathrm{C}$ & $-150^{\circ} \mathrm{C}$ \\
\hline$\theta$ range & $4.5-54.9$ & $5.0-54.9$ & $4.3-54.9$ & $4.3-54.9$ \\
\hline reflns collected & 15472 & 6968 & 17294 & 8534 \\
\hline unique reflns & 7444 & 3581 & 3433 & 4209 \\
\hline$R_{\text {int }}$ & 0.045 & 0.045 & 0.034 & 0.041 \\
\hline$R_{1}(I>2 \sigma(I))^{\mathrm{a}}$ & 0.054 & 0.058 & 0.038 & 0.037 \\
\hline$R_{1}, w R_{2}$ (all data) $)^{\mathrm{b}}$ & $0.085,0.153$ & $0.096,0.172$ & $0.061,0.105$ & $0.072,0.99$ \\
\hline $\mathrm{GOF}^{\mathrm{C}}$ & 1.87 & 1.87 & 1.11 & 1.41 \\
\hline
\end{tabular}

a). $R_{1}=\Sigma|| F_{\mathrm{o}}|-| F_{\mathrm{c}}|| / \Sigma\left|F_{\mathrm{o}}\right|$ for $I>2 \sigma(I)$ data. b). $R_{\mathrm{w}}=\left\{\Sigma w\left(\left|F_{\mathrm{o}}\right|-\left|F_{\mathrm{c}}\right|\right)^{2} \Sigma w F_{\mathrm{o}}^{2}\right\}^{1 / 2}$. 
TABLE S2. Crystal data and structural refinement for trans-8 and 9.

\begin{tabular}{|c|c|c|}
\hline & trans-8 & trans-9 \\
\hline empirical formura & $\mathrm{C} 24 \mathrm{H} 28$ & $\mathrm{C} 42 \mathrm{H} 36$ \\
\hline crystal habit, color & prizmatic, colorless & prizmatic, colorless \\
\hline$M\left(\mathrm{~g} \mathrm{~mol}^{-1}\right)$ & 316.48 & 540.74 \\
\hline cryst. syst. & $\mathrm{P}-1(\# 2)$ & $\mathrm{P}-1(\# 2)$ \\
\hline space group & triclinic & triclinic \\
\hline $\mathrm{a}(\AA)$ & $9.5186(3)$ & $11.2423(10)$ \\
\hline $\mathrm{b}(\AA)$ & $12.2793(4)$ & $11.7930(11)$ \\
\hline$c(\AA)$ & $16.6625(7)$ & $13.3567(10)$ \\
\hline$\alpha$ (deg.) & $98.6777(15)$ & $108.197(2)$ \\
\hline$\beta$ (deg.) & $97.2329(19)$ & $105.652(5)$ \\
\hline$\gamma$ (deg.) & $102.8273(11)$ & $108.365(2)$ \\
\hline$V\left(\AA^{3}\right)$ & $1851.35(11)$ & $1457.4(2)$ \\
\hline Z & 4 & 2 \\
\hline$D_{\text {calcd }}\left(\mathrm{g} \mathrm{cm}^{-1}\right)$ & 1.497 & 1.232 \\
\hline$\mu(\mathrm{Mo} \mathrm{K} \alpha)\left(\mathrm{mm}^{-1}\right)$ & 0.08 & 0.07 \\
\hline$F(000)$ & 1088 & 576 \\
\hline$T(\mathrm{~K})$ & $-160^{\circ} \mathrm{C}$ & $-160^{\circ} \mathrm{C}$ \\
\hline$\theta$ range & $1.3-27.5$ & $1.8-27.5$ \\
\hline reflns collected & 16558 & 6032 \\
\hline unique reflns & 6329 & 3757 \\
\hline$R_{\text {int }}$ & 0.065 & 0.065 \\
\hline$R_{1}(I>2 \sigma(I))^{\mathrm{a}}$ & 0.051 & 0.070 \\
\hline$R_{1}, w R_{2}$ (all data) ${ }^{b}$ & $0.070,0.153$ & $0.116,0.205$ \\
\hline $\mathrm{GOF}^{\mathrm{c}}$ & 1.05 & 1.07 \\
\hline
\end{tabular}

a). $R_{\mathrm{l}}=\Sigma|| F_{\mathrm{o}}|-| F_{\mathrm{c}}|| / \Sigma\left|F_{\mathrm{o}}\right|$ for $I>2 \sigma(I)$ data. b). $R_{\mathrm{w}}=\left\{\Sigma \mathrm{w}\left(\left|F_{\mathrm{o}}\right|-\left|F_{\mathrm{c}}\right|\right)^{2} / \Sigma w F_{\mathrm{o}}^{2}\right\}^{1 / 2}$.

(A)

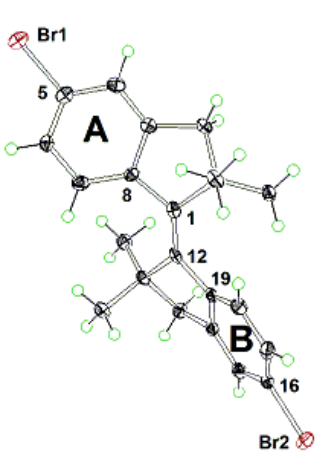

(B)

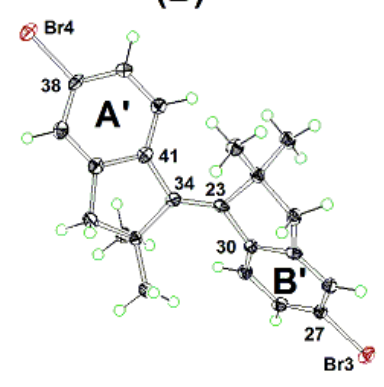

(C)

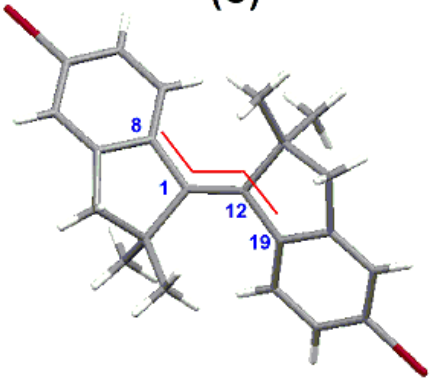

FIGURE S1. ORTEP drawing of trans-2. Two crystallographically independent molecules (A and $\mathbf{B})$ are observed in the unit cell. The atoms are drawn as 50\% probability ellipsoids. Selected bond lengths $(\AA)$ and dihedral angles $\left({ }^{\circ}\right)$ of trans-2 for (A): C1-C12; 1.357 (2), C23-C34; 1.357 (2), C8-C1-C12-C19; 166.4 (1), C30-C23-C34-C41; 167.5 (1), and (B): C23-C34; 1.361 (5), C30-C23-C34-C41; -164.9 (3). (C) Indicate the twist angle of $\mathrm{C}=\mathrm{C}$ double bond of trans-2. 


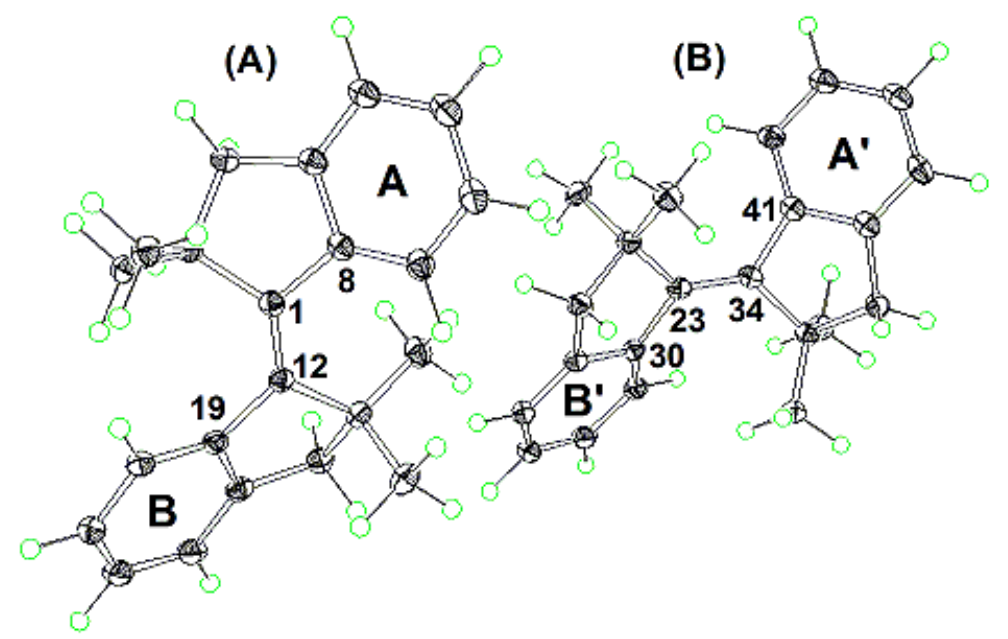

FIGURE S2. ORTEP drawing of trans-1. Two crystallographically independent molecules (A and B) are observed in the unit cell. The atoms are drawn at $50 \%$ probability ellipsoids. Selected bond lengths ( $\AA$ ) and dihedral angles ( $)$ for (A): C1-C12; 1.357 (5), C8-C1-C12-C19; -166.4 (3), > A-B; 68.3. Selected bond lengths ( $\AA$ ) and dihedral angles ( ${ }^{\circ}$ ) for (B): C23-C34; 1.357 (5), C30-C23-C34-C41;-167.5 (3), >A'-B'; 71.3.
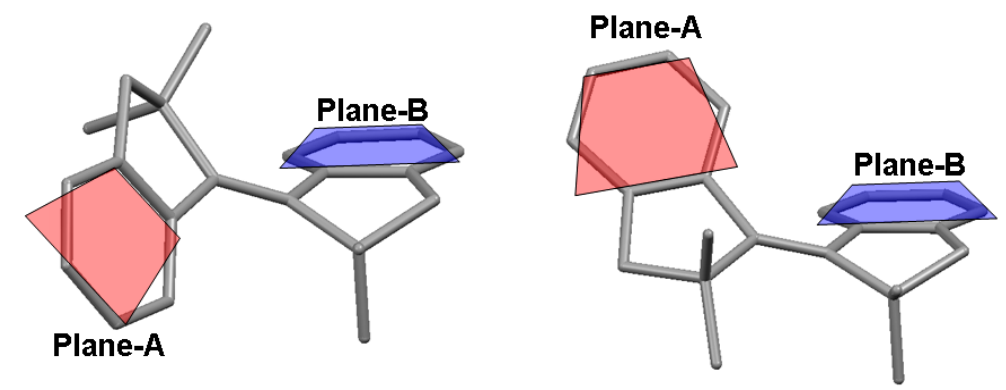

FIGURE S3. Parameters of $>\mathrm{A}-\mathrm{B}$ for 1 and 2.

(A)

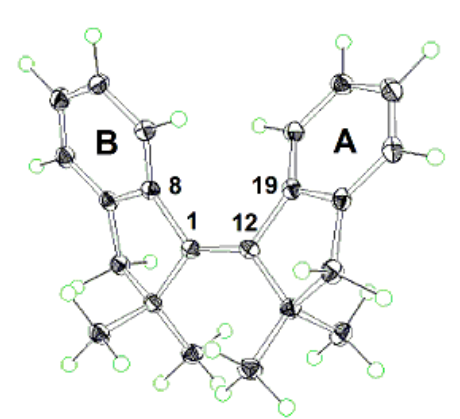

(B)

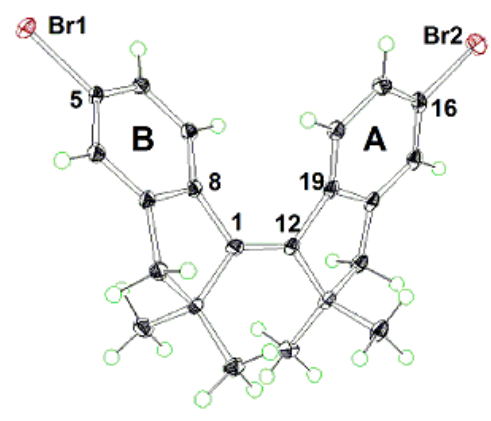

(C)

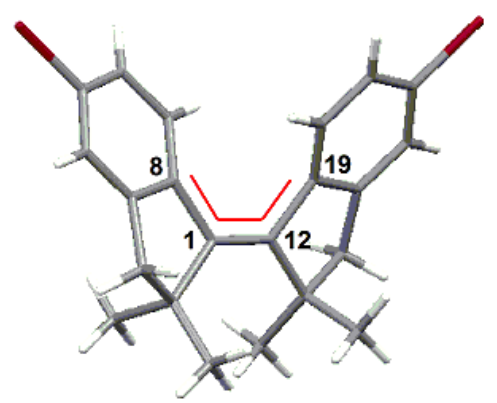

FIGURE S4. ORTEP drawing of cis-1 (A) and cis-2 (B) with thermal ellipsoids at $50 \%$ probability. Selected bond lengths $(\AA)$ and dihedral angle (') of cis-1 (A): C1-C12: 1.355 (2), C8-C1-C12-C19: -18.6 (2), > A - B: 63.2, and cis-2 (B). C1-C12: 1.362 (4), Br5-C1: 1.906 (3), Br2-C16: 1.898 (3), C8-C1-C12-C19: 18.0 (4), > A - B:: 50.6. (C). Indicate the twist angle of C=C double bond of cis-1 and 2. 


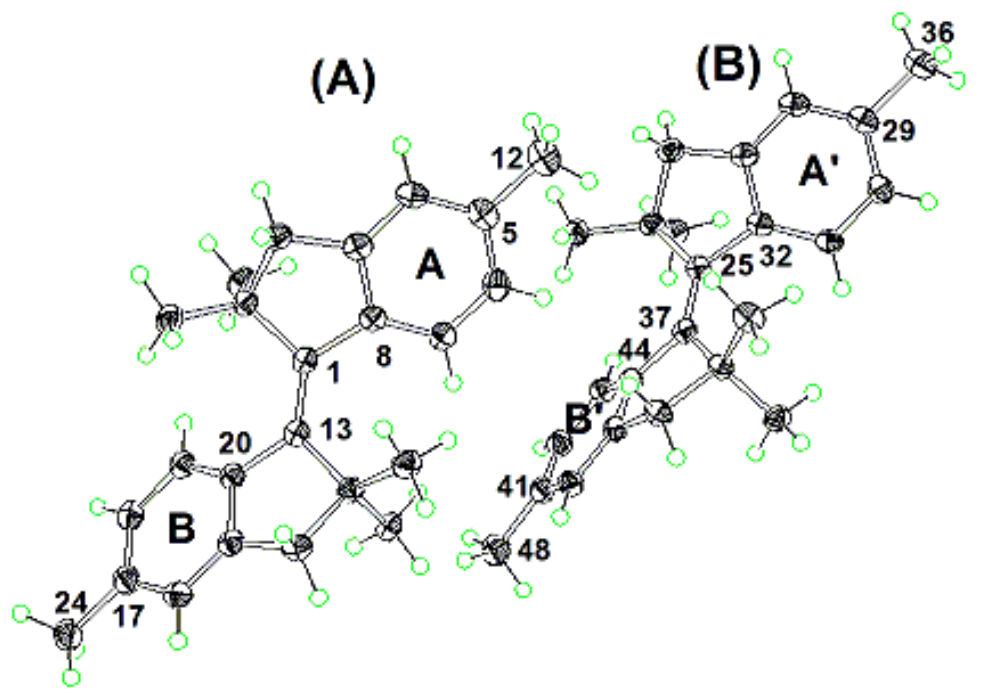

FIGURE S5. ORTEP drawing of trans-8. Two crystallographically independent molecules (A and $\mathbf{B})$ are observed in the unit cell. The atoms are drawn at $50 \%$ probability ellipsoids. Selected bond lengths ( $\AA$ ) and dihedral angles ( $)$ for (A): C1-C13; 1.357 (19), C5-C12, 1.524 (2), C17-C24, 1.538 (2), C8-C1-C13-C20; 168.8 (13), > A-B; 63.4. Selected bond lengths $(\AA)$ and dihedral angles $\left({ }^{\circ}\right)$ for (B): C25-C37; 1.360 (18), C29-C36, 1.537 (2), C41-C48, 1.530 (19), C30-C23-C34-C41;-167.2 (13), > A-B; 61.1.

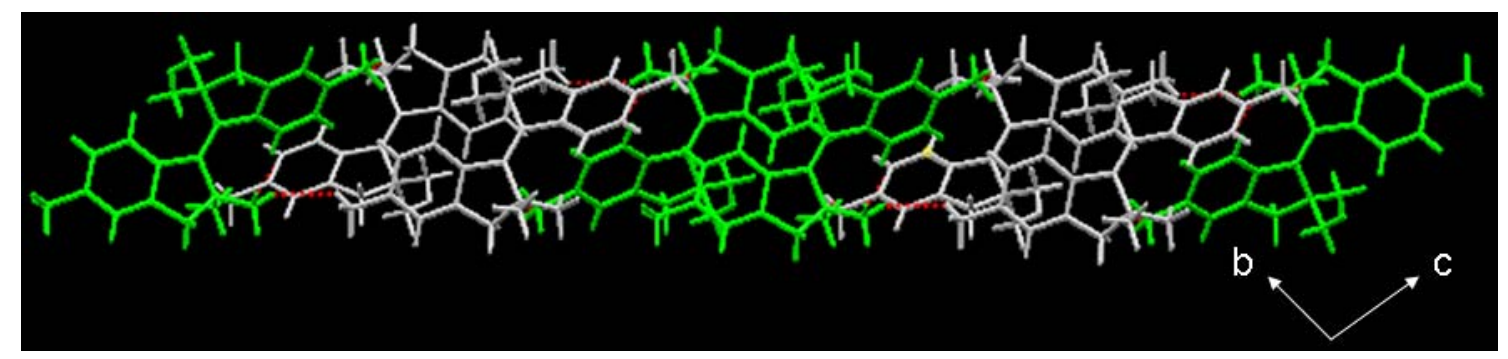

FIGURE S6. Top view of crystal packing of trans-8.

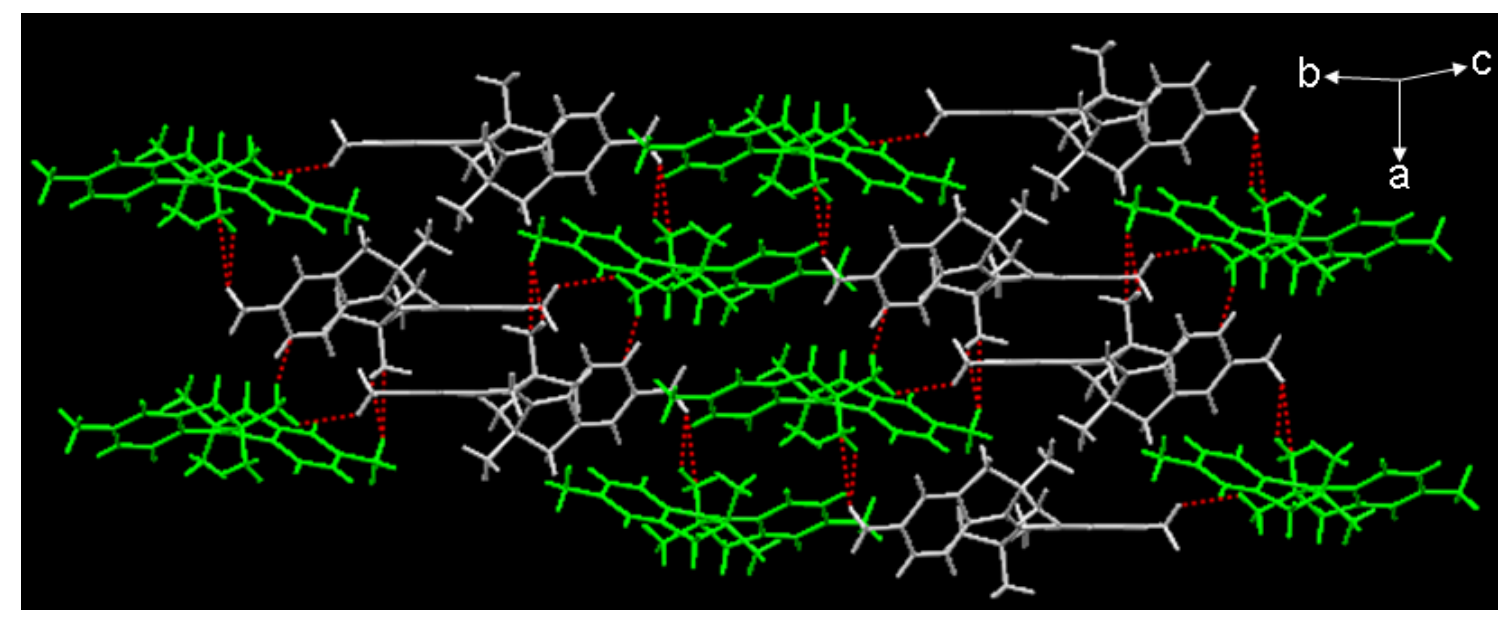

FIGURE S7. Side view of crystal packing of trans-8. 


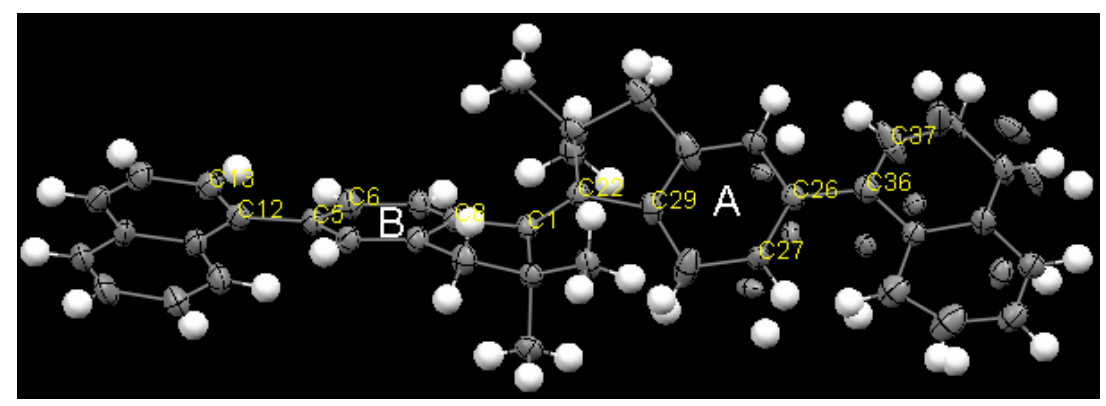

FIGURE S8. X-ray crystal structure of trans -9 with thermal ellipsoids at $50 \%$ probability. Selected bond lengths ( $(\AA)$ and dihedral angles ( ${ }^{\circ}$ ) of trans-9: C1-C22; 1.363 (3), C5-C12, 1.500 (3), C26-C36, 1.496 (6), C8-C1-C22-C29; -169.4 (3), C13-C12-C5-C6; -131.5 (3), C27-C26-C36-C37;-123.6 (7).

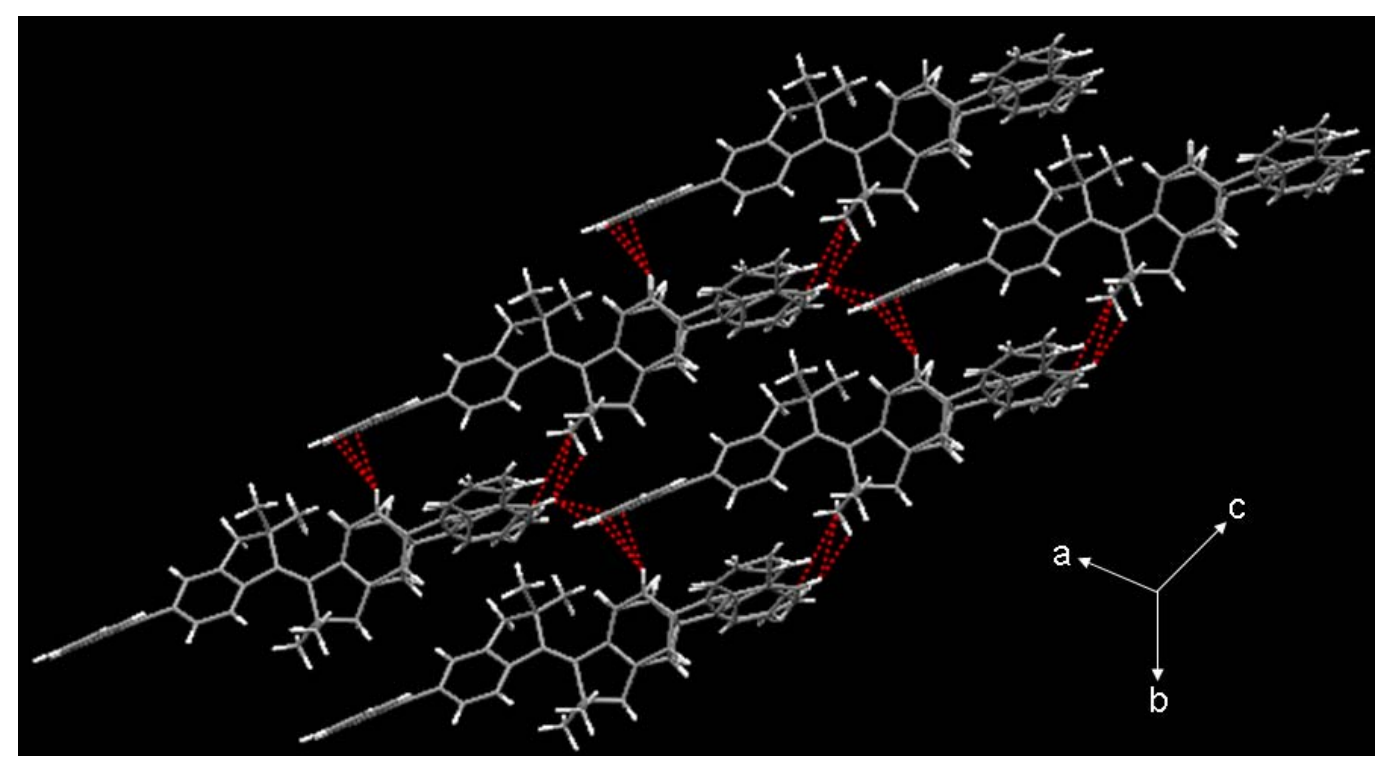

FIGURE S9. Crystal packing of trans-9.

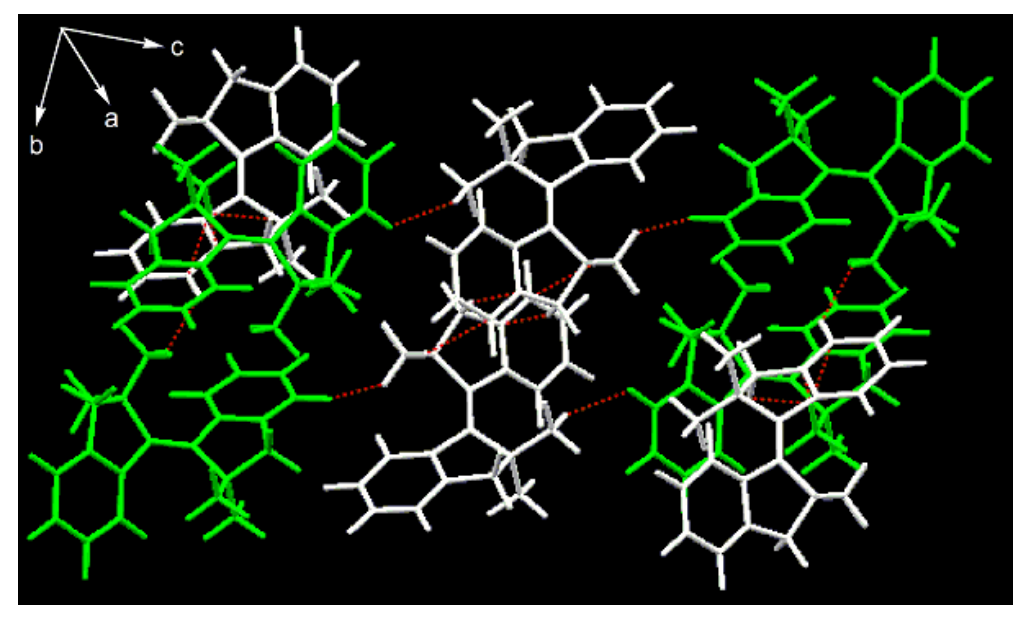

FIGURE S10. Crystal packing of trans-1. 


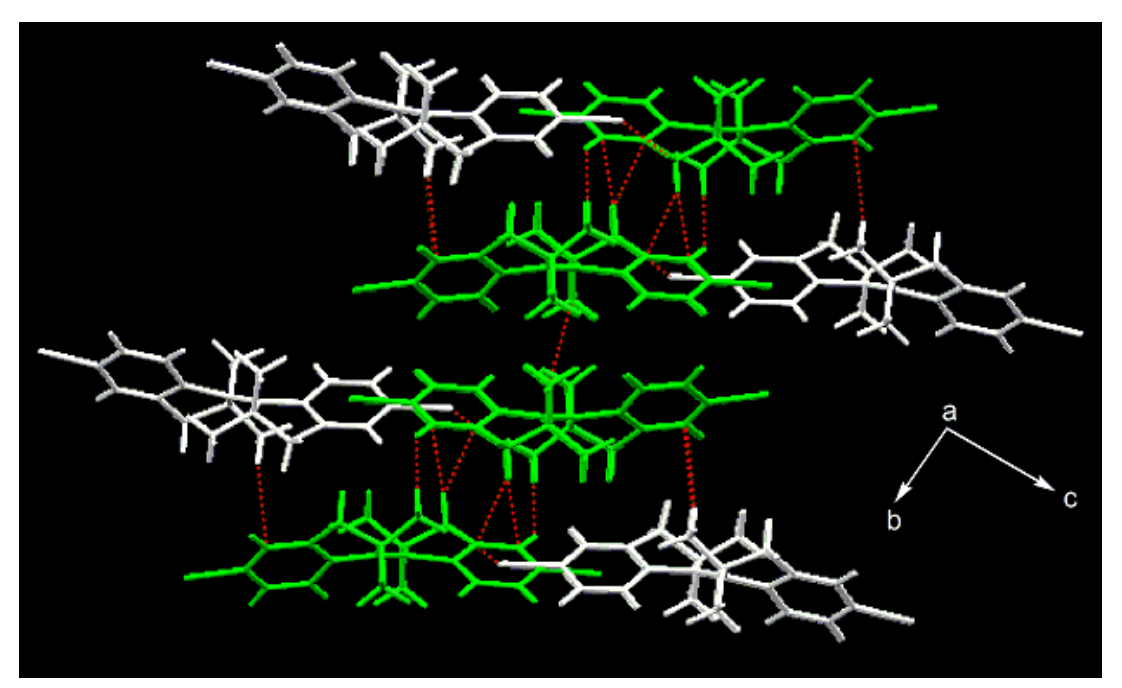

FIGURE S11. Top view of crystal packing of trans-2.

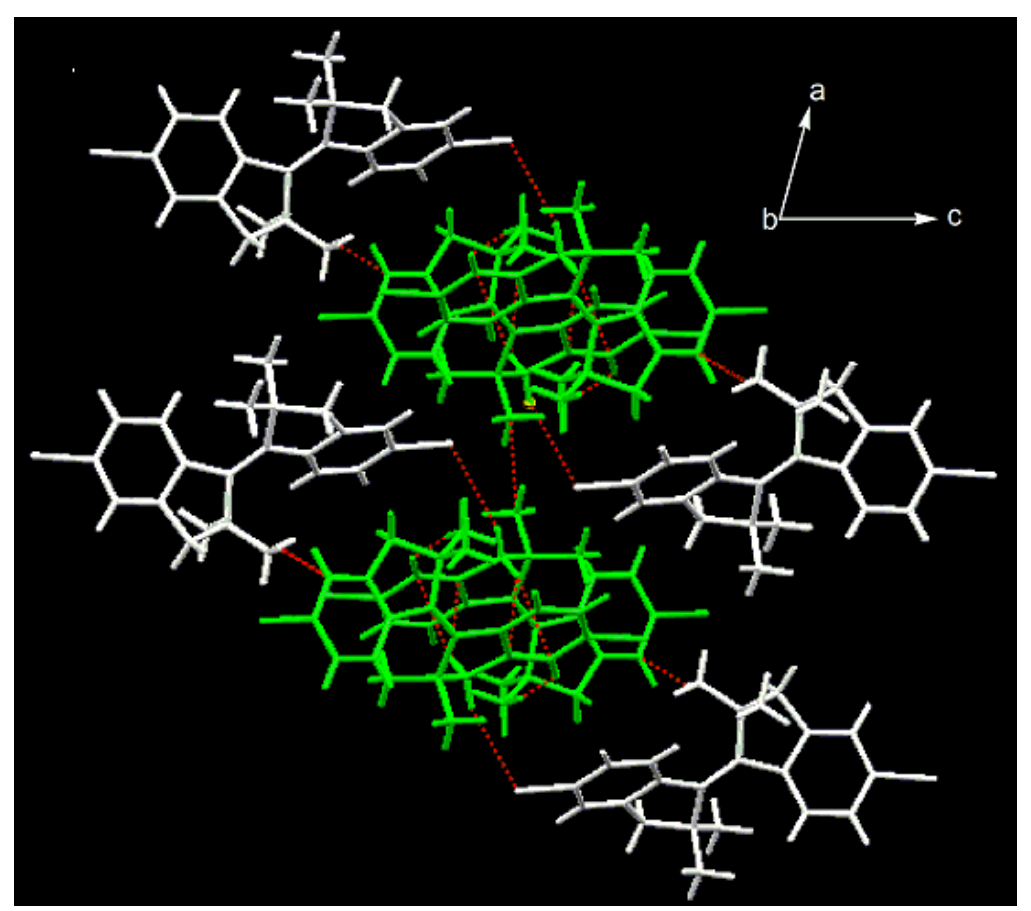

FIGURE S12. Front view of crystal packing of trans-2. 


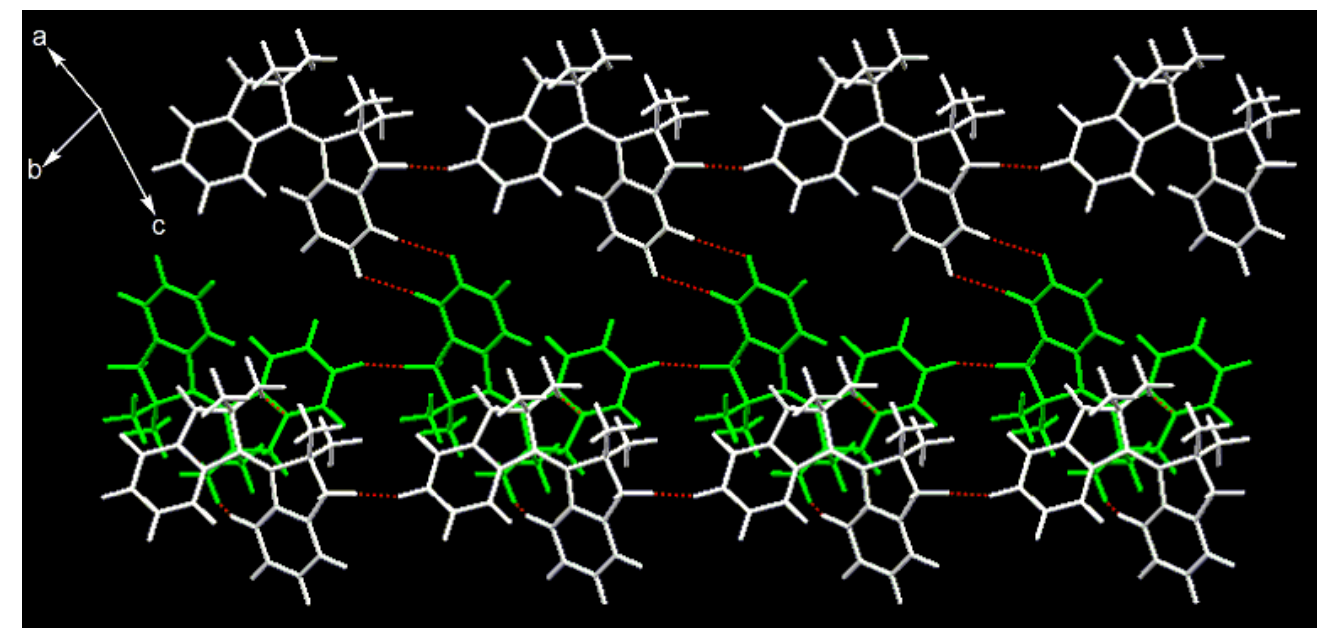

FIGURE S13. Front view of crystal packing of cis-1.

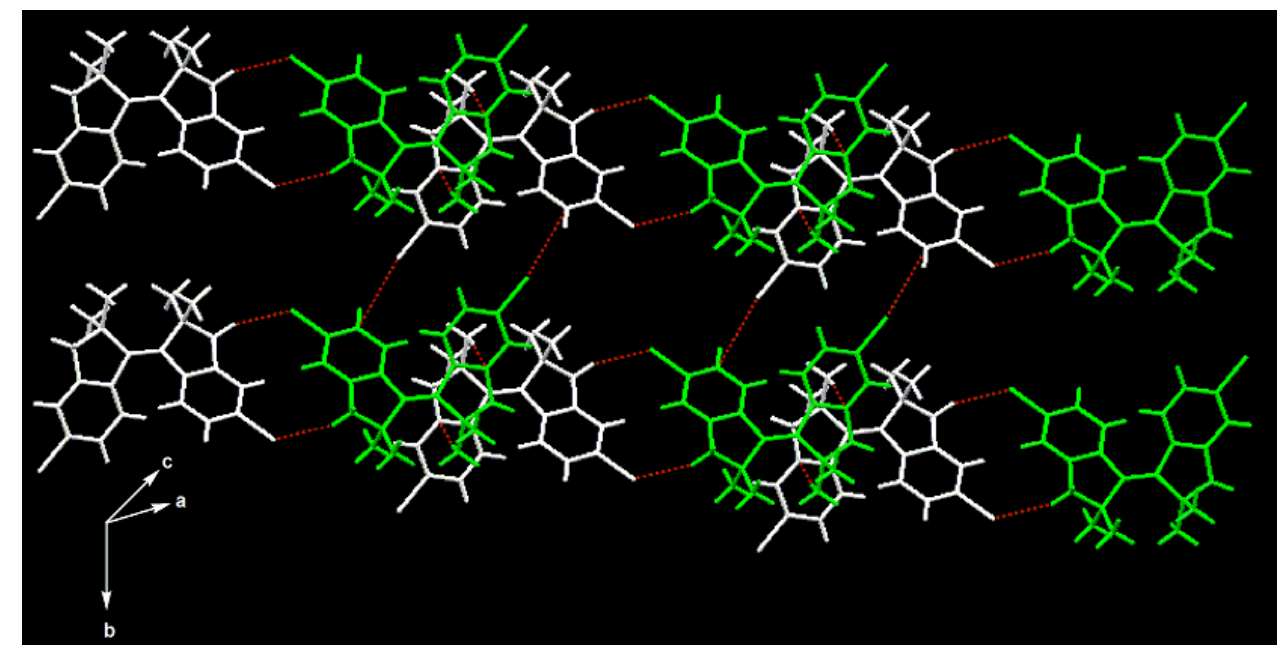

FIGURE S14. Front view of crystal packing of cis-2.

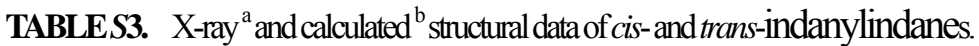

\begin{tabular}{|c|c|c|c|c|c|c|}
\hline & \multirow{2}{*}{\multicolumn{2}{|c|}{$\frac{\text { Bond lengths (Angstrom) }}{\text { C1-C1' }}$}} & \multicolumn{4}{|c|}{ Angles (degree) } \\
\hline & & & \multicolumn{2}{|c|}{ C8-C1-C1'-C8' } & \multicolumn{2}{|c|}{$>A-B$} \\
\hline & observed & calcd. & observed & calcd. & observed & calcd. \\
\hline trans-1 & 1.357 & 1.364 & 166.9 & 167.2 & 69.8 & 66.5 \\
\hline trans-2 & 1.356 & 1.365 & 164.1 & 167.0 & 51.0 & 66.1 \\
\hline trans-8 & 1.359 & 1.367 & 168.0 & 167.2 & 62.2 & 66.4 \\
\hline trans-9 & 1.364 & 1.365 & 169.4 & 167.0 & $57.6-59.1^{\mathrm{C}}$ & 64.9 \\
\hline cis-1 & 1.354 & 1.365 & 18.5 & 18.7 & 63.2 & 51.2 \\
\hline cis-2 & 1.362 & 1.366 & 17.8 & 18.6 & 50.6 & 50.8 \\
\hline
\end{tabular}

${ }^{\mathrm{a} X} \mathrm{X}$-ray structural values of the trans-1 and $\mathbf{2}$ are averages of two of independent molecules. ${ }^{\mathrm{b}}$ Structural optimizations were carried out at DFT // B3LYP / 6-31G* level of theory. ${ }^{c}$ Disorder was observed in trans-9. 
5. NMR spectra.

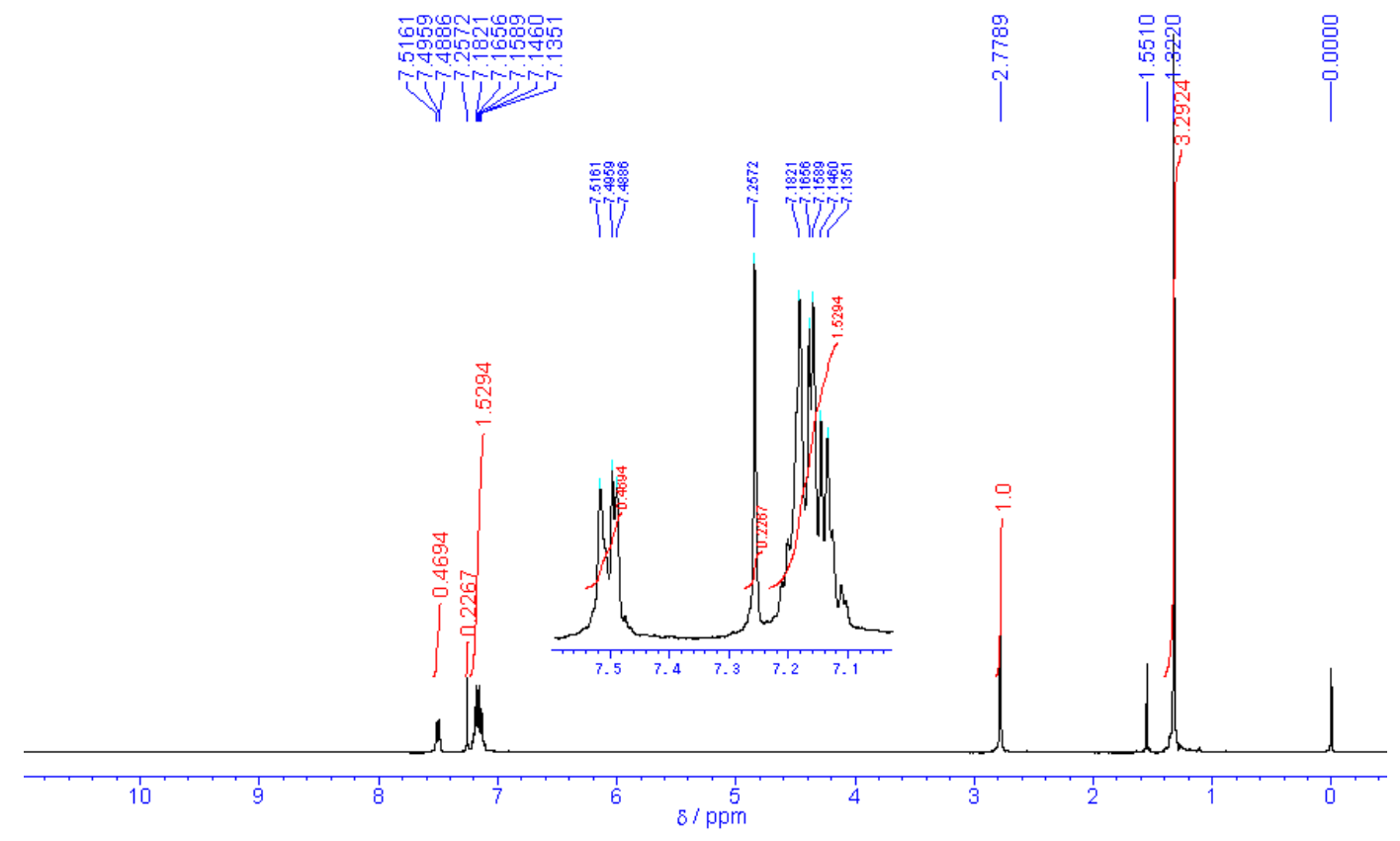

FIGURE S15. $\quad{ }^{1} \mathrm{H}$ NMR spectrum of trans-1 (300 MHz).

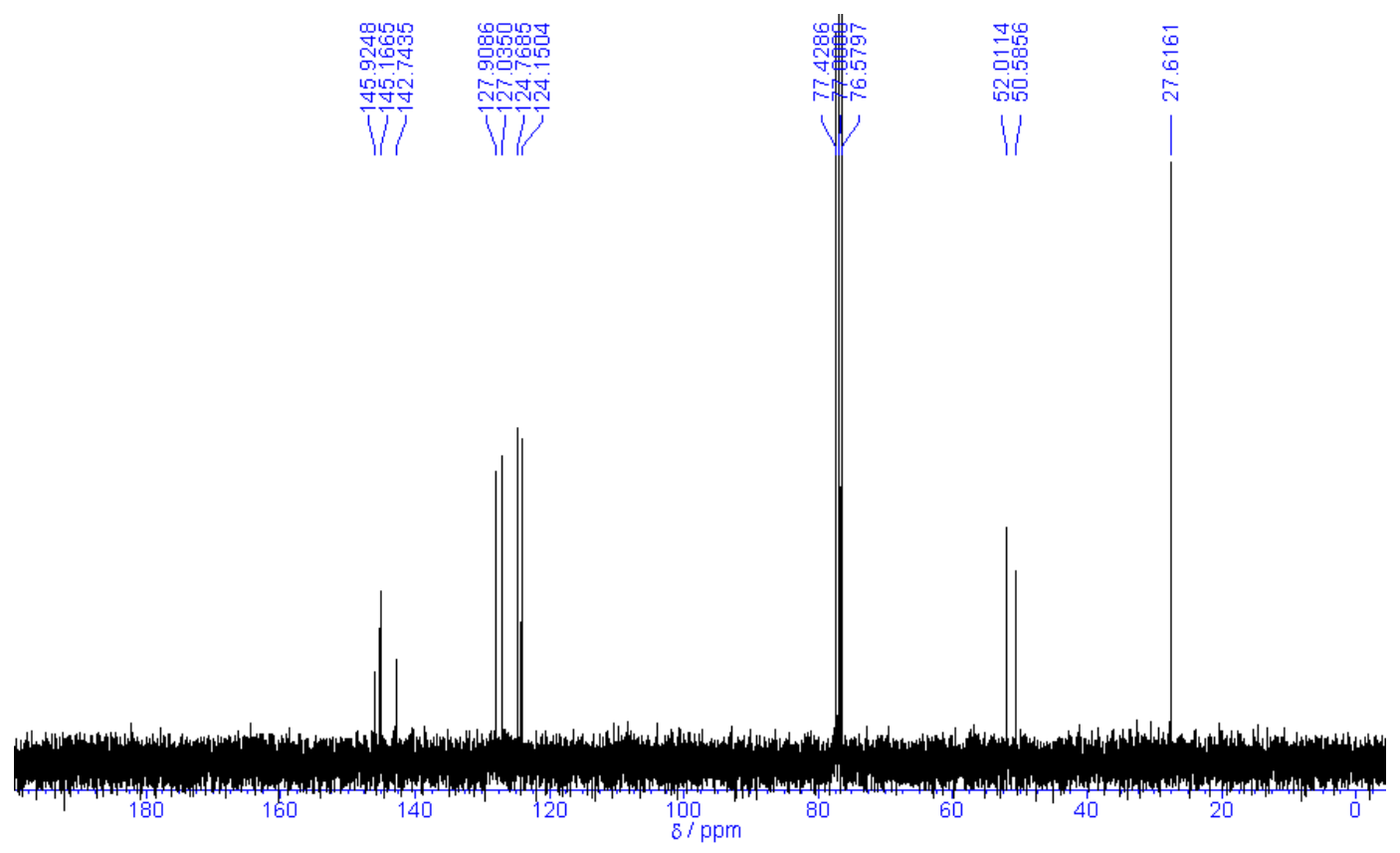

FIGURE S16. ${ }^{13} \mathrm{C}$ NMR spectrum of trans-1 (75 MHz). 


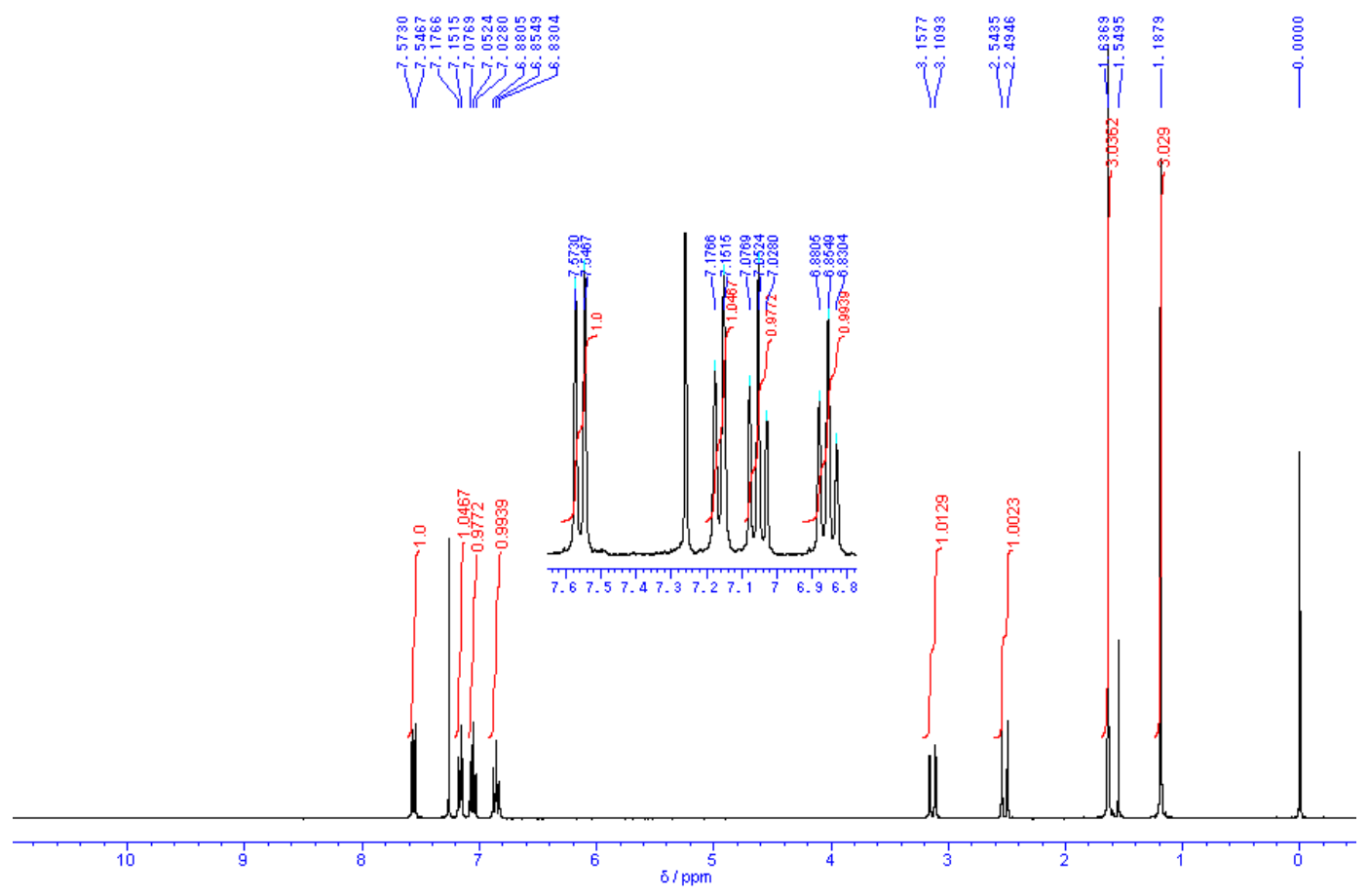

FIGURE S17. ${ }^{1} \mathrm{H}$ NMR spectrum of cis-1 (300 MHz).

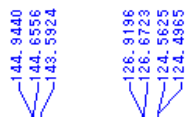

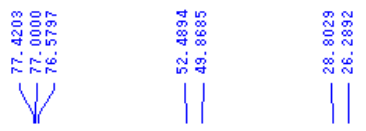

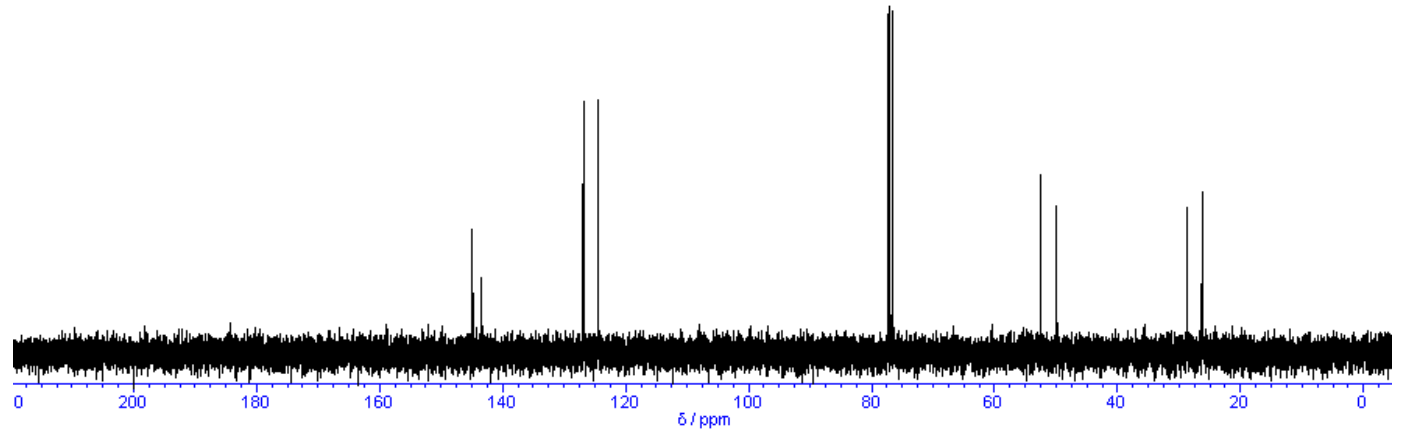

FIGURE S18. ${ }^{13} \mathrm{C}$ NMR spectrum of cis-1 $(75 \mathrm{MHz})$. 


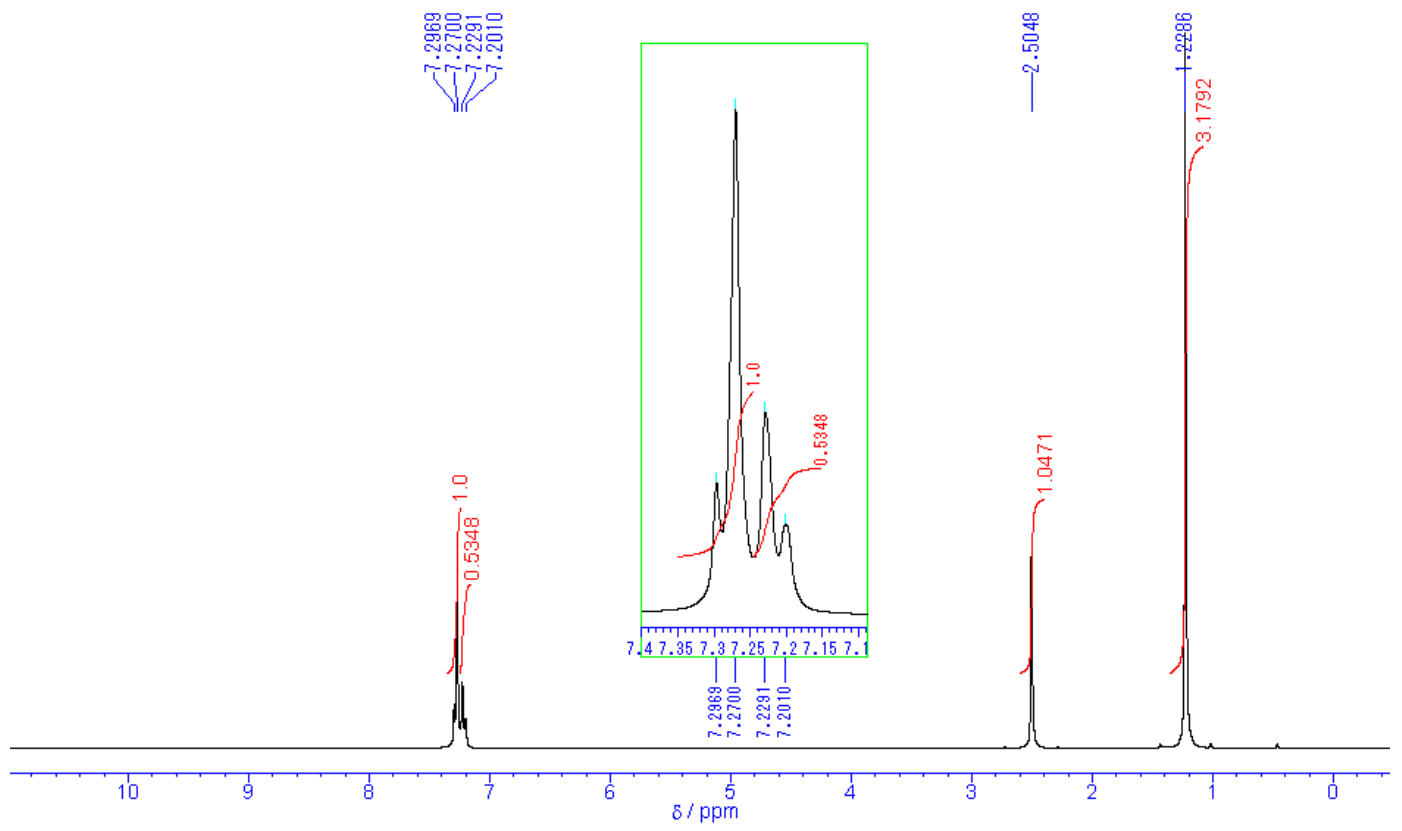

FIGURE S19. ${ }^{1} \mathrm{H}$ NMR spectrum of trans-2 (300 MHz).

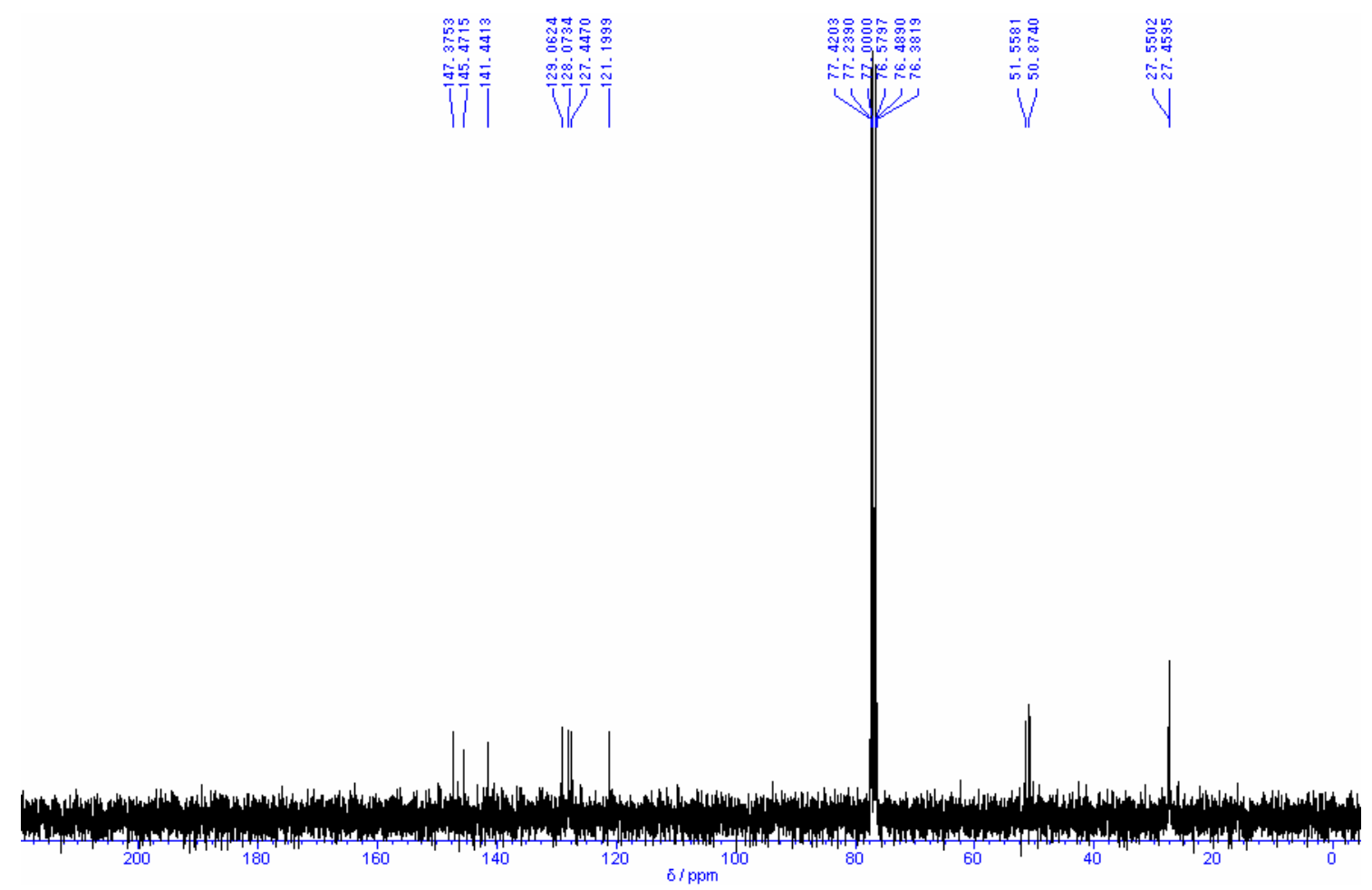

FIGURE S20 ${ }^{13} \mathrm{C}$ NMR spectrum of trans-2 (75 MHz). 


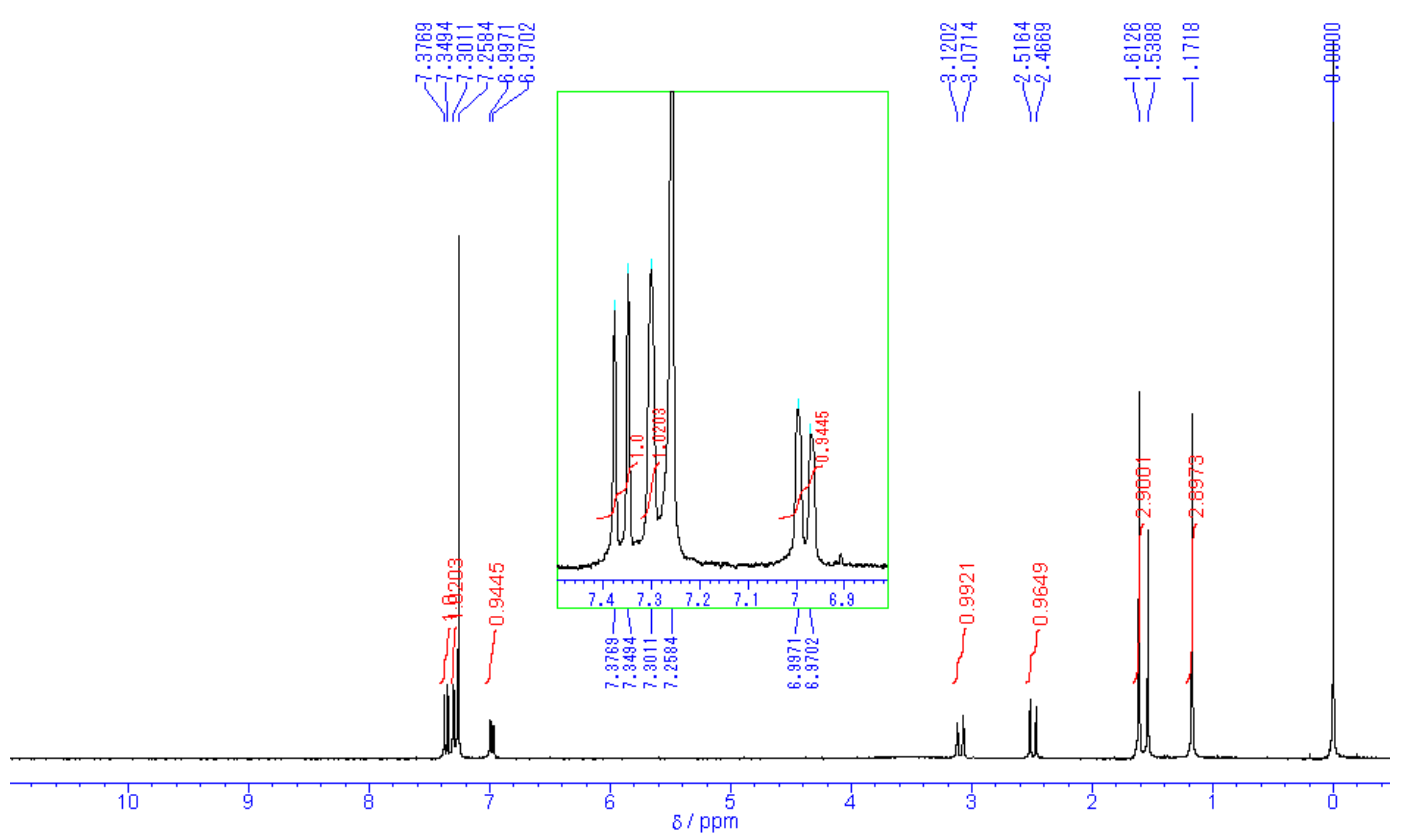

FIGURE S21. ${ }^{1} \mathrm{H}$ NMR spectrum of cis-2 (300 MHz).

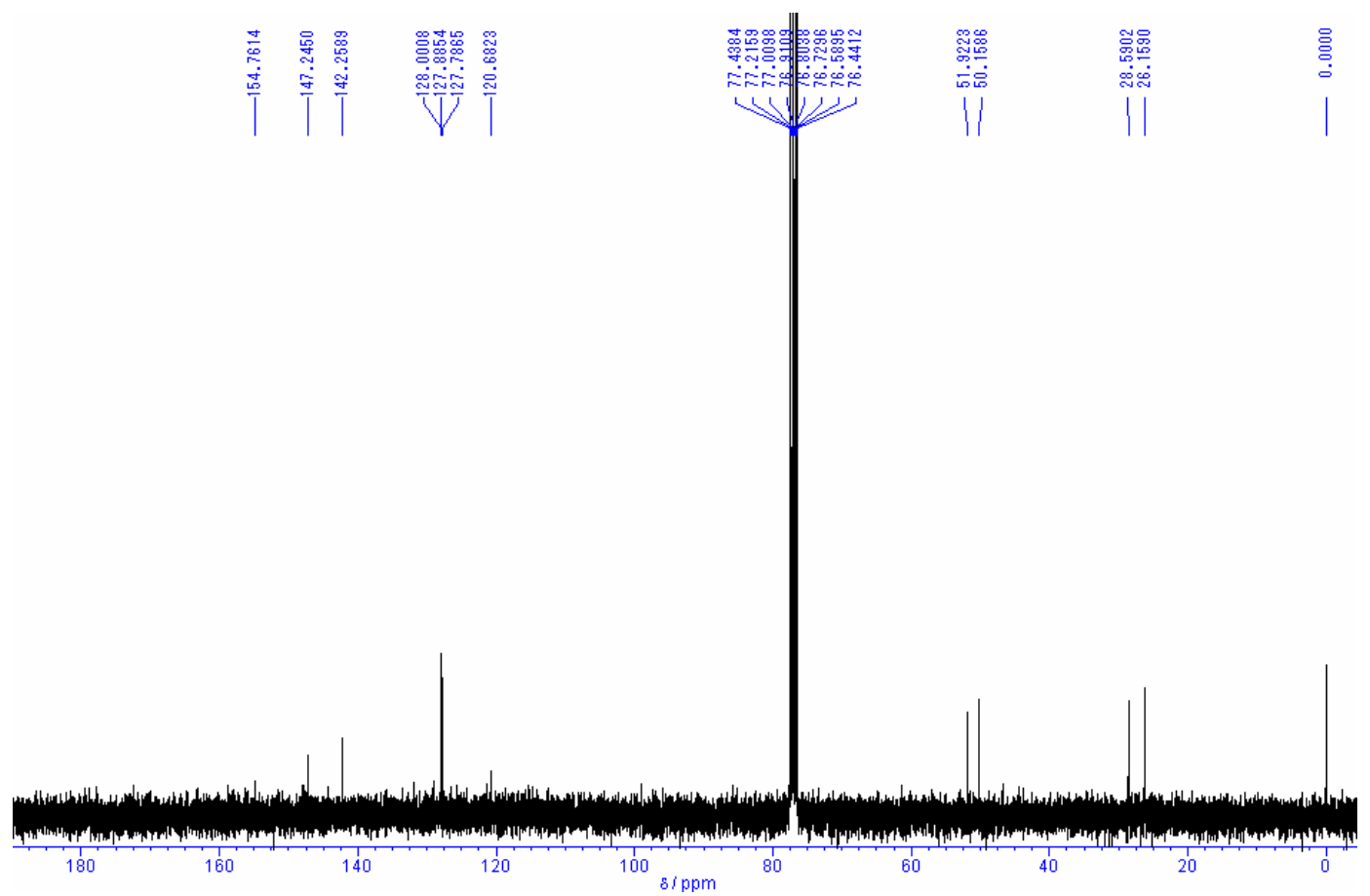

FIGURE S22. ${ }^{13} \mathrm{C}$ NMR spectrum of cis-2 (75 MHz). 


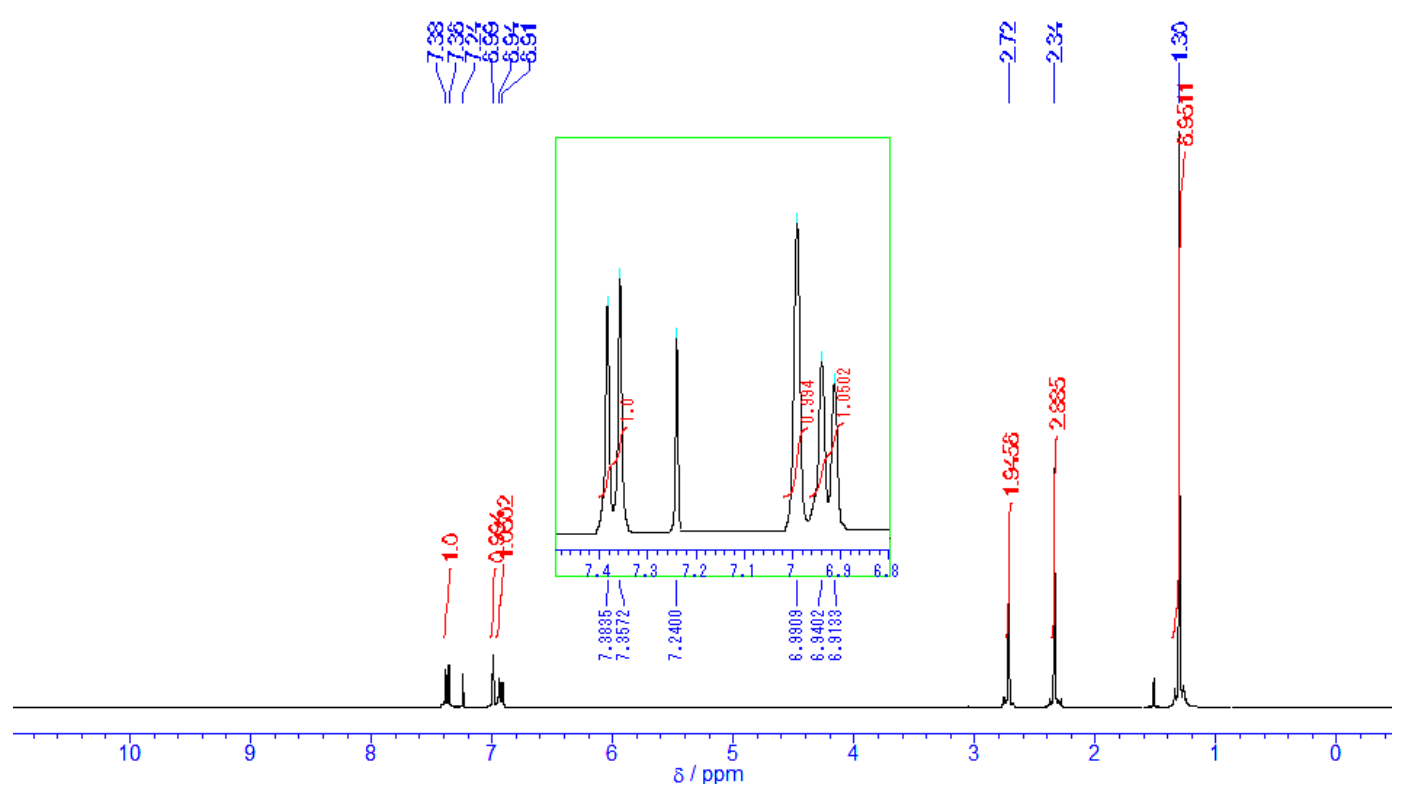

FIGURE S23. ${ }^{1} \mathrm{H}$ NMR spectrum of trans-8 (300 MHz).

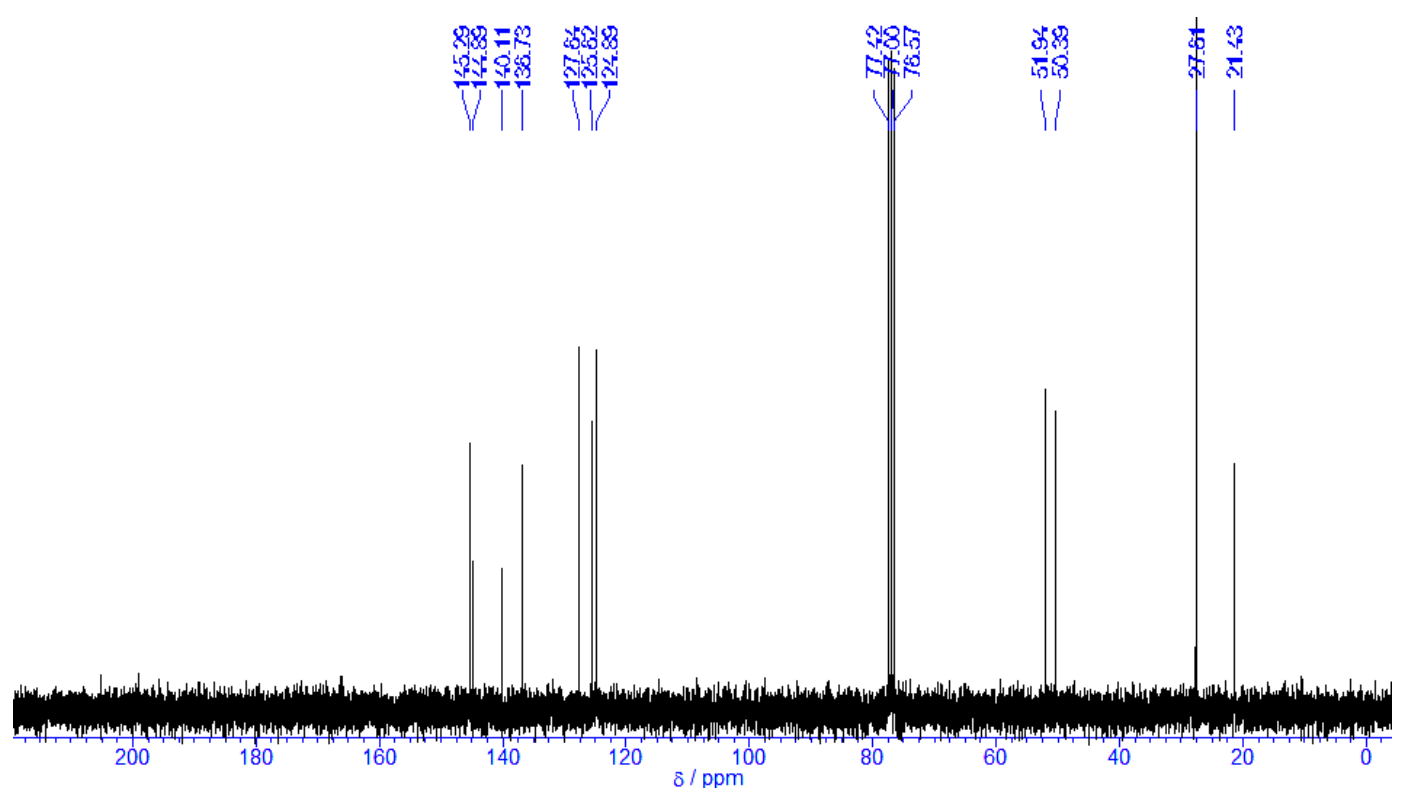

FIGURE S24. ${ }^{13} \mathrm{C}$ NMR spectrum of trans-8 $(75 \mathrm{MHz})$. 


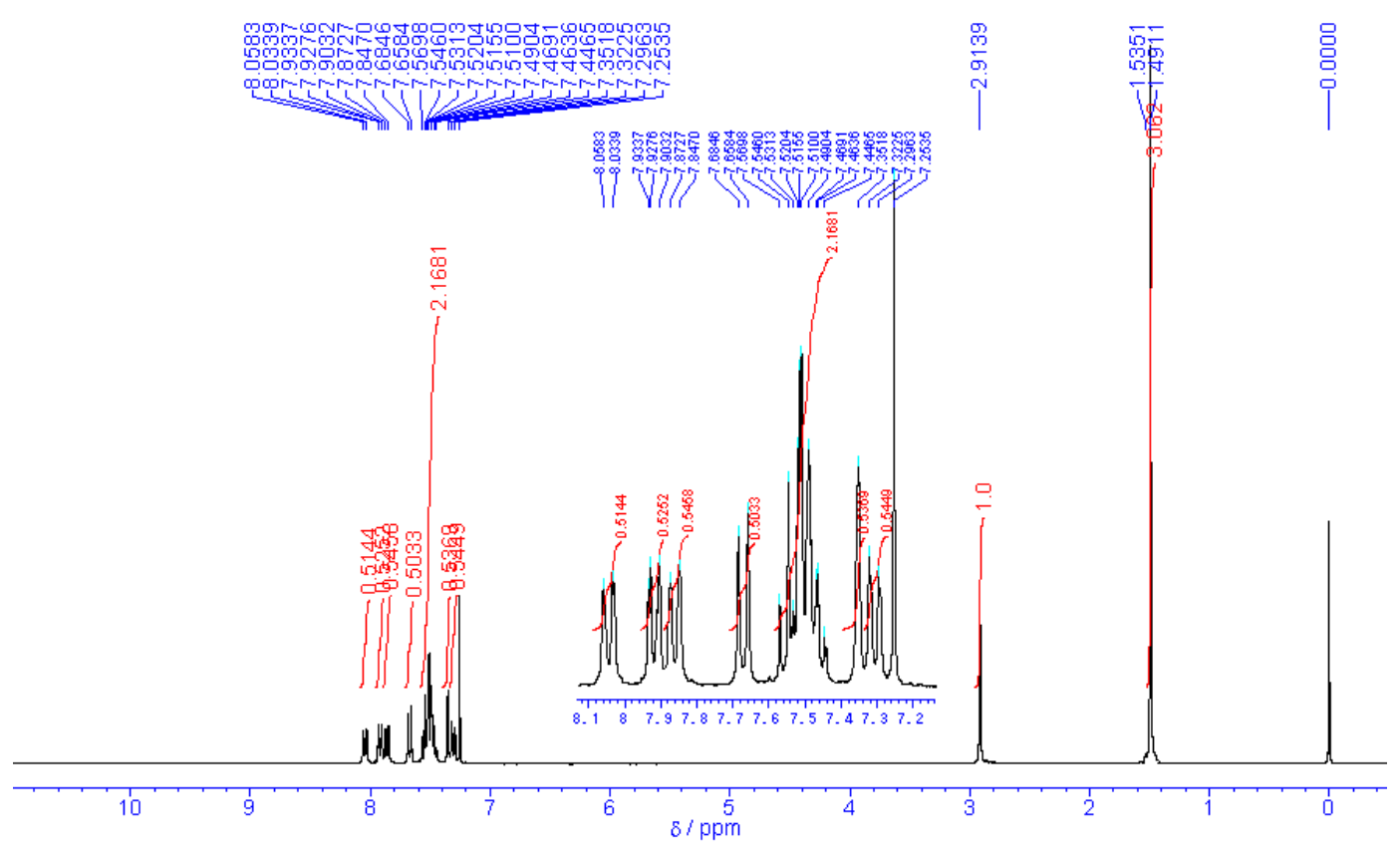

FIGURE S25. $\quad{ }^{1} \mathrm{H}$ NMR spectrum of trans-9 (300 MHz).

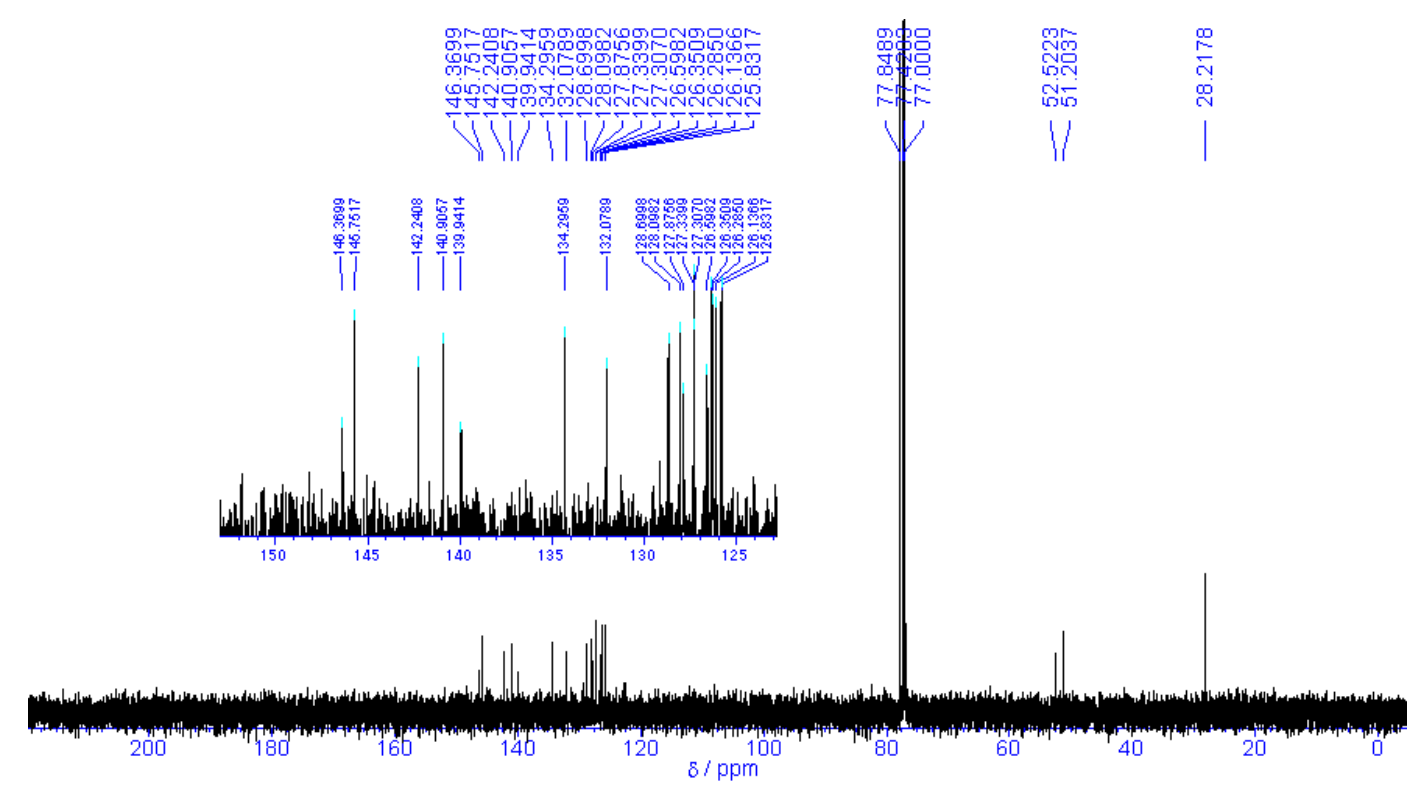

FIGURE S26. ${ }^{13} \mathrm{C}$ NMR spectrum of trans-9 $(75 \mathrm{MHz})$. 


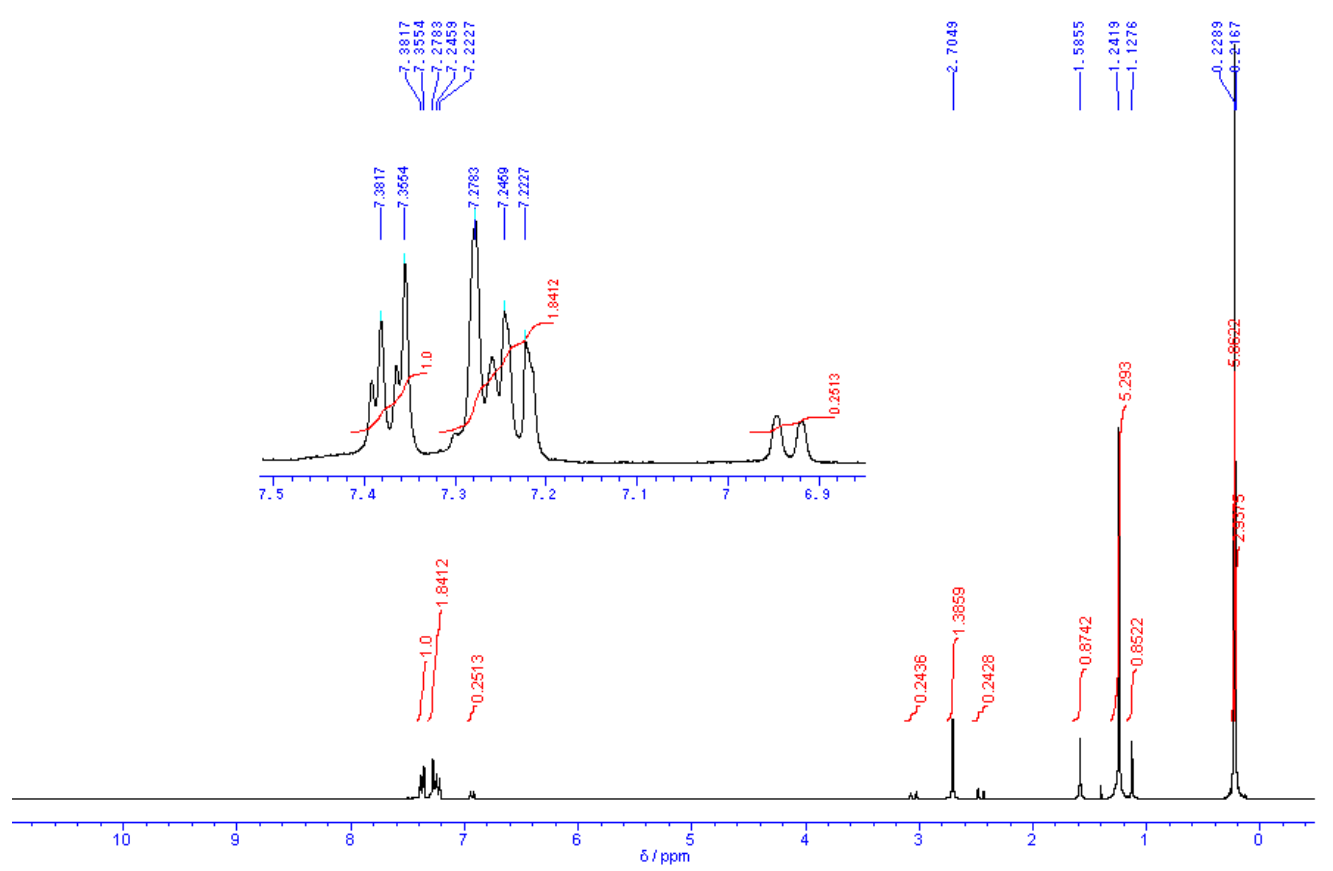

FIGURE S27. ${ }^{1} \mathrm{H}$ NMR spectrum of a mixture of trans-10 and cis-10 (300 MHz).

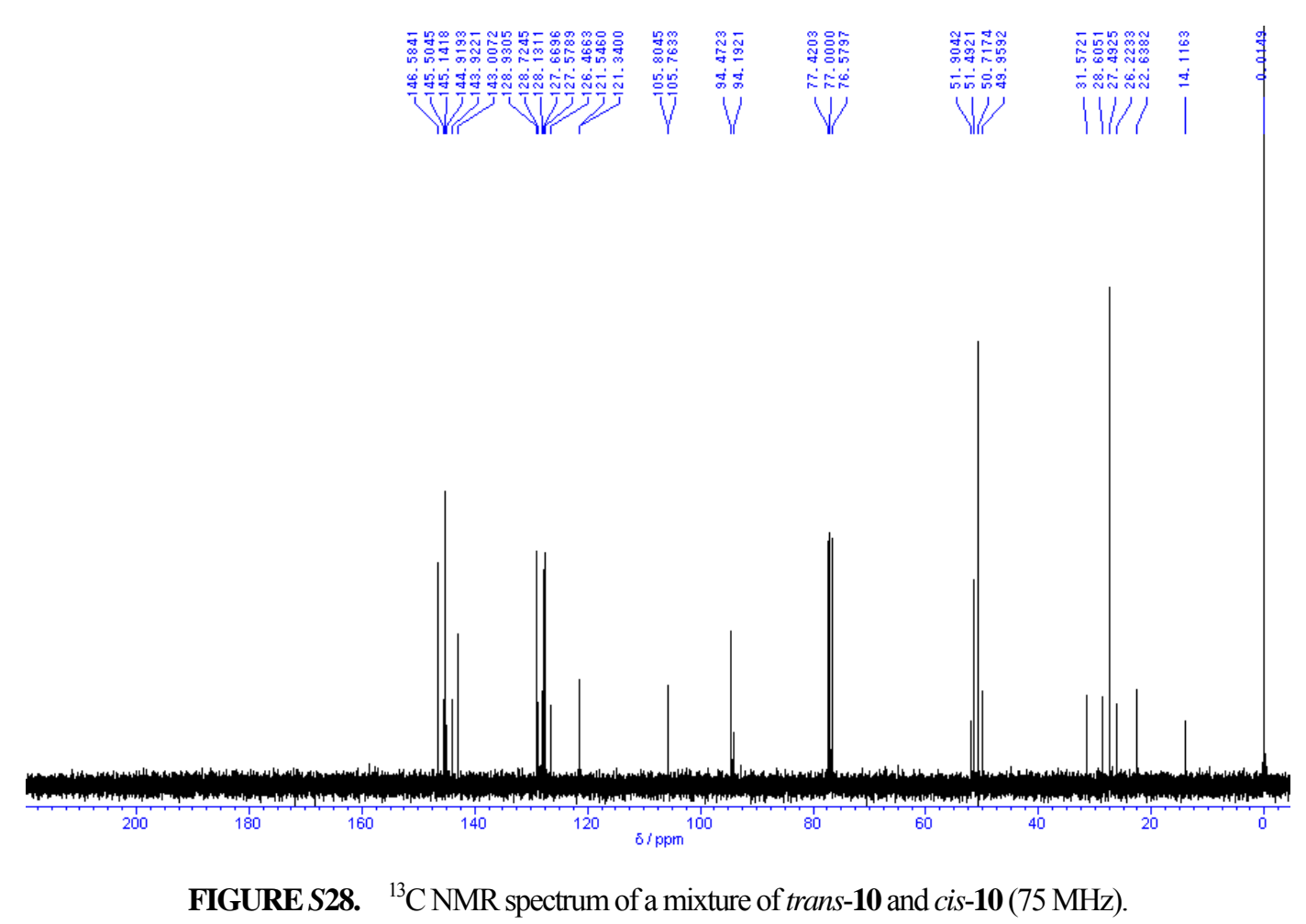




\section{Comparison of rate of trans-cis photoisomerization between 1 and azobenzene. ${ }^{7}$}

We compared the rate of the photochemical isomerization of both of cis- and trans-1 with azobenzene upon irradiation at 254 and ca. $380 \mathrm{~nm}$ light, respectively, at $23{ }^{\circ} \mathrm{C}$ in benzene, and the reactions were monitored by ${ }^{1} \mathrm{H}$ NMR spectra. Irradiation of a benzene solution of the pure trans-1 with $254 \mathrm{~nm}$-light for 5 min afforded a 23 / 77 (cis / trans) mixture, and this isomerization was faster than that of azobenzene by ca. 10 times (20 / 80 after 50-min irradiation). On the other hand, the rate of the photochemical isomerization from cis-1 to trans-1 [20 / 80 (cis / trans) after ca. 12-min] was faster than that of azobenzene by ca. 1.5 times (22 / 78 after 20-min irradiation) in benzene. Comparison of the rates of the trans to cis photoisomerization between $\mathbf{1}$ and azobenzene in benzene and those of the reverse isomerization were summarized in Figures S26and S27, respectively.

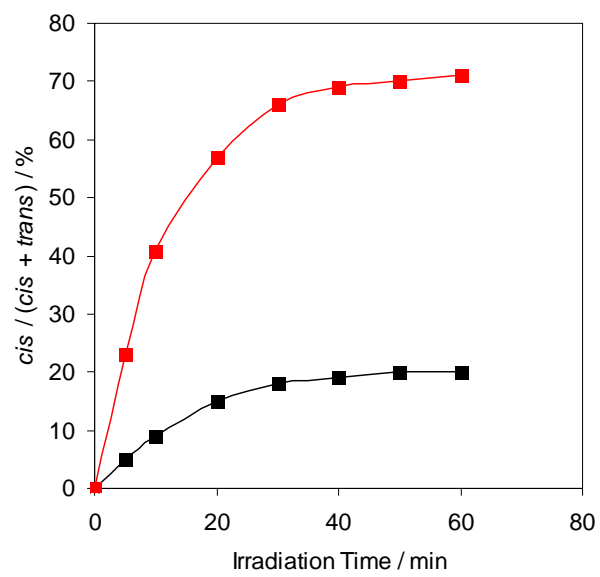

FIGURE S29. Comparison of rate of trans to cis photo-isomerization between $\mathbf{1}$ and azobenzene under irradiation at $254 \mathrm{~nm}$ light in benzene. Red line: 1 in benzene. Black line: azobenzene in benzene.

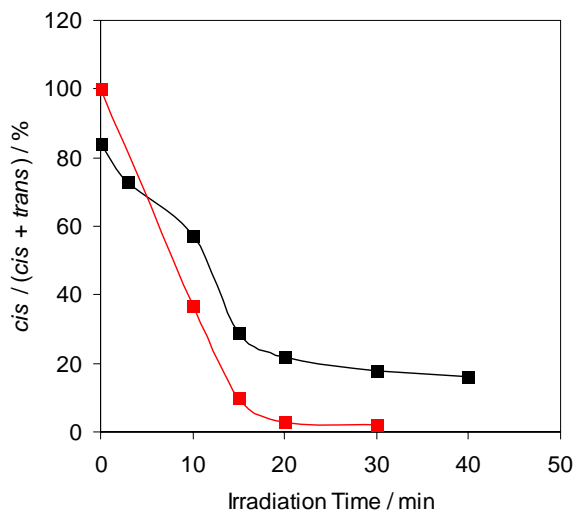

FIGURE S30. Comparison of rate of cis to trans photo-isomerization between 1 and azobenzene in benzene. Red line: 1 under irradiation at ca. $380 \mathrm{~nm}$ light in benzene. Black line: azobenzene in benzene. 


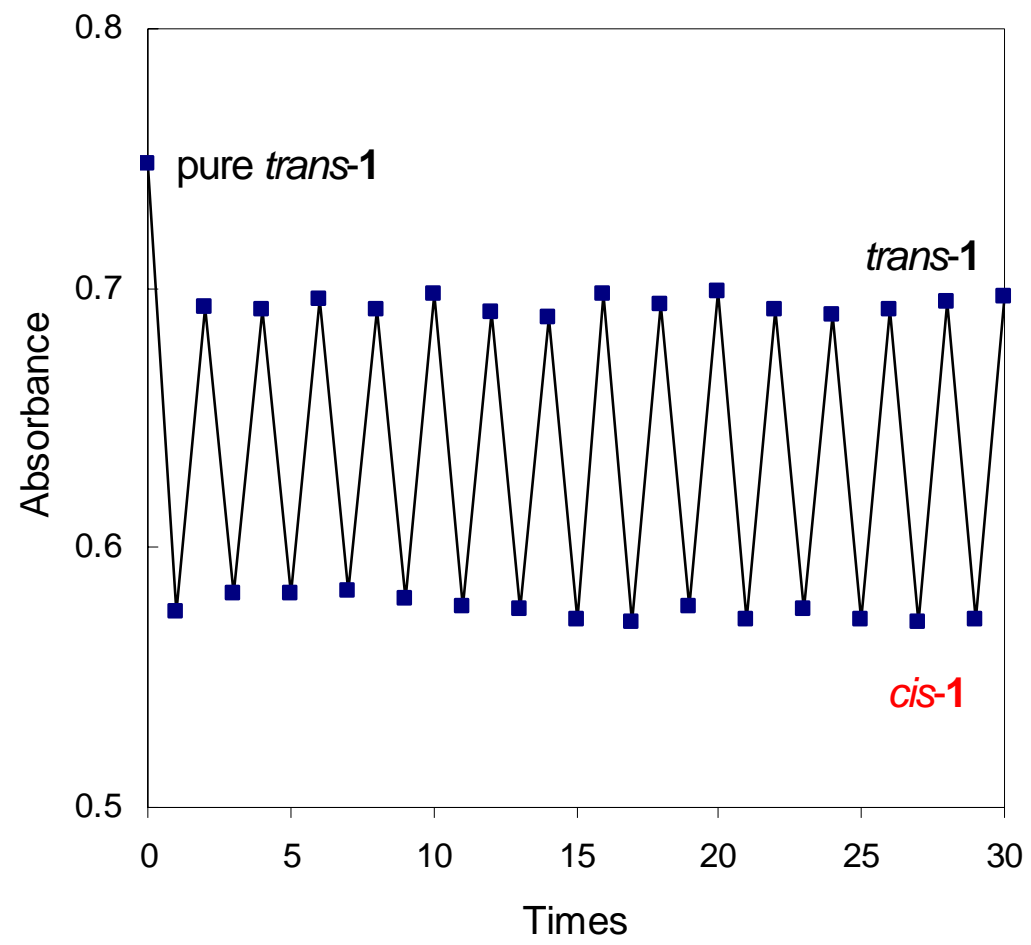

FIGURE S31. Repetitive switching experiments were carried out by monitoring the $326 \mathrm{~nm}$ absorption band; irradiation of the trans-1 with $254 \mathrm{~nm}$-light, whereas irradiation of the cis-1 with ca. $380 \mathrm{~nm}$ light in $\mathrm{CH}_{3} \mathrm{CN}$ solution at $23^{\circ} \mathrm{C}$.

\section{Theoretical calculations.}

TABLE S4. Coordinate of the trans-thiirane 6 at the B3LYP / 6-31G* level of theory.
$\begin{array}{lll}0 & 1\end{array}$
C $\quad-4.65648$
$0.01275-0.32199$
$\begin{array}{llll}\text { C } & -4.21603 & 0.75733 & 0.77322\end{array}$
$\begin{array}{llll}\text { C } & -2.88858 & 0.64825 & 1.19054\end{array}$
$\begin{array}{llll}\text { C } & -2.01050 & -0.18273 & 0.49412\end{array}$
$\begin{array}{llll}\text { C } & -2.49054 & -0.96906 & -0.55962\end{array}$
$\begin{array}{llll}\text { C } & -3.81114 & -0.87189 & -0.99106\end{array}$
$\begin{array}{llll}\text { C } & -0.55983 & -0.52504 & 0.78181\end{array}$
$\begin{array}{llll}\text { C } & -0.44947 & -2.00108 & 0.21286\end{array}$
$\begin{array}{llll}\text { C } & -1.41952 & -1.92170 & -1.01093\end{array}$
$\begin{array}{llll}\mathrm{S} & 0.00007 & 0.00023 & 2.46889\end{array}$
$\begin{array}{llll}\text { C } & -1.02321 & -2.97190 & 1.26644\end{array}$
$\begin{array}{llll}\text { C } & 0.89841 & -2.54942 & -0.26627\end{array}$
$\begin{array}{llll}\mathrm{Br} & -6.47949 & 0.16821 & -0.88379\end{array}$
$\begin{array}{llll}\text { C } & 0.55989 & 0.52527 & 0.78173\end{array}$
$\begin{array}{llll}\text { C } & 0.44955 & 2.00121 & 0.21255\end{array}$
$\begin{array}{llll}\text { C } & 1.41945 & 1.92158 & -1.01133\end{array}$ 


$\begin{array}{llcc}\mathrm{C} & 2.49050 & 0.96899 & -0.55997 \\ \mathrm{C} & 2.01053 & 0.18285 & 0.49395 \\ \mathrm{C} & 3.81106 & 0.87171 & -0.99150 \\ \mathrm{C} & 4.65643 & -0.01285 & -0.32236 \\ \mathrm{C} & 4.21605 & -0.75724 & 0.77300 \\ \mathrm{C} & 2.88864 & -0.64805 & 1.19043 \\ \mathrm{C} & 1.02347 & 2.97219 & 1.26589 \\ \mathrm{C} & -0.89836 & 2.54949 & -0.26655 \\ \mathrm{Br} & 6.47938 & -0.16845 & -0.88430 \\ \mathrm{H} & -4.90856 & 1.40220 & 1.30288 \\ \mathrm{H} & -2.54785 & 1.19530 & 2.06352 \\ \mathrm{H} & -4.18745 & -1.48261 & -1.80532 \\ \mathrm{H} & -0.88281 & -1.53397 & -1.88925 \\ \mathrm{H} & -1.80709 & -2.91065 & -1.28178 \\ \mathrm{H} & -1.07510 & -3.98701 & 0.85563 \\ \mathrm{H} & -2.02900 & -2.68330 & 1.58733 \\ \mathrm{H} & -0.37970 & -2.99602 & 2.15206 \\ \mathrm{H} & 0.71249 & -3.51147 & -0.76069 \\ \mathrm{H} & 1.59349 & -2.73635 & 0.55419 \\ \mathrm{H} & 1.38960 & -1.89514 & -0.99074 \\ \mathrm{H} & 1.80701 & 2.91046 & -1.28243 \\ \mathrm{H} & 0.88263 & 1.53368 & -1.88951 \\ \mathrm{H} & 4.18733 & 1.48229 & -1.80590 \\ \mathrm{H} & 4.90861 & -1.40205 & 1.30270 \\ \mathrm{H} & 2.54796 & -1.19495 & 2.06352 \\ \mathrm{H} & 1.07537 & 3.98721 & 0.85488 \\ \mathrm{H} & 2.02927 & 2.68355 & 1.58670 \\ \mathrm{H} & 0.38007 & 2.99650 & 2.15158 \\ \mathrm{H} & -0.71250 & 3.51141 & -0.76123 \\ \mathrm{H} & -1.59336 & 2.73664 & 0.55393 \\ \mathrm{H} & -1.38965 & 1.89503 & -0.99080\end{array}$

TABLE S5. Coordinate of the cis-thiirane 6 at the B3LYP / 6-31G* level of theory.

\begin{tabular}{|c|c|c|c|}
\hline $\mathrm{C}$ & 3.22769 & -1.23645 & 0.07681 \\
\hline $\mathrm{C}$ & 2.56658 & -1.06646 & 1.29222 \\
\hline $\mathrm{C}$ & 1.66387 & -0.01051 & 1.44344 \\
\hline $\mathrm{C}$ & 1.41079 & 0.84668 & 0.37356 \\
\hline C & 2.15459 & 0.70741 & -0.80498 \\
\hline $\mathrm{C}$ & 3.05309 & -0.34042 & -0.97803 \\
\hline $\mathrm{C}$ & 0.52569 & 2.08537 & 0.28543 \\
\hline 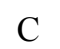 & 1.38568 & 2.98231 & -0.70113 \\
\hline
\end{tabular}




\begin{tabular}{|c|c|c|c|}
\hline $\mathrm{C}$ & 1.92366 & 1.89983 & -1.68928 \\
\hline $\mathrm{C}$ & -1.00958 & 1.89970 & 0.45061 \\
\hline S & -0.16718 & 2.68648 & 1.88653 \\
\hline $\mathrm{C}$ & 2.55241 & 3.57592 & 0.12497 \\
\hline $\mathrm{C}$ & 0.77950 & 4.12850 & -1.50526 \\
\hline $\mathrm{C}$ & -1.53750 & 0.47166 & 0.46414 \\
\hline $\mathrm{C}$ & -2.43325 & 0.31322 & -0.60683 \\
\hline $\mathrm{C}$ & -2.69621 & 1.64499 & -1.26495 \\
\hline $\mathrm{C}$ & -2.26763 & 2.65300 & -0.16214 \\
\hline $\mathrm{C}$ & -1.34082 & -0.58544 & 1.34914 \\
\hline $\mathrm{C}$ & -1.95272 & -1.81962 & 1.10874 \\
\hline $\mathrm{C}$ & -2.77259 & -1.97550 & -0.00635 \\
\hline $\mathrm{C}$ & -3.04363 & -0.90925 & -0.86504 \\
\hline $\mathrm{C}$ & -3.33581 & 2.68238 & 0.96778 \\
\hline $\mathrm{C}$ & -2.19128 & 4.09243 & -0.67667 \\
\hline $\mathrm{Br}$ & 4.45854 & -2.68753 & -0.12502 \\
\hline $\mathrm{Br}$ & -3.59734 & -3.67157 & -0.33148 \\
\hline $\mathrm{H}$ & 2.76817 & -1.74010 & 2.11787 \\
\hline $\mathrm{H}$ & 1.20410 & 0.16508 & 2.40930 \\
\hline $\mathrm{H}$ & 3.63157 & -0.44521 & -1.89014 \\
\hline $\mathrm{H}$ & 1.17140 & 1.69383 & -2.46483 \\
\hline $\mathrm{H}$ & 2.83282 & 2.23580 & -2.20147 \\
\hline $\mathrm{H}$ & 3.27171 & 4.06732 & -0.54045 \\
\hline $\mathrm{H}$ & 3.08767 & 2.81660 & 0.70153 \\
\hline $\mathrm{H}$ & 2.17298 & 4.32722 & 0.82584 \\
\hline $\mathrm{H}$ & 1.58499 & 4.59415 & -2.08627 \\
\hline $\mathrm{H}$ & 0.34534 & 4.90438 & -0.87261 \\
\hline $\mathrm{H}$ & 0.03240 & 3.78302 & -2.22198 \\
\hline $\mathrm{H}$ & -2.08107 & 1.78652 & -2.16598 \\
\hline $\mathrm{H}$ & -3.74339 & 1.77173 & -1.56355 \\
\hline $\mathrm{H}$ & -0.75035 & -0.45680 & 2.24602 \\
\hline $\mathrm{H}$ & -1.80229 & -2.64829 & 1.79175 \\
\hline $\mathrm{H}$ & -3.73779 & -1.03051 & -1.69050 \\
\hline $\mathrm{H}$ & -3.05427 & 3.41947 & 1.72734 \\
\hline $\mathrm{H}$ & -3.46815 & 1.71860 & 1.46445 \\
\hline $\mathrm{H}$ & -4.30270 & 2.98418 & 0.54943 \\
\hline $\mathrm{H}$ & -3.21211 & 4.48174 & -0.76467 \\
\hline $\mathrm{H}$ & -1.73653 & 4.17804 & -1.66081 \\
\hline $\mathrm{H}$ & -1.65704 & 4.73932 & 0.02544 \\
\hline
\end{tabular}

TABLE S6. Coordinate of the trans-1 at the B3LYP / 6-31G* level of theory. 


\begin{tabular}{|c|c|c|c|}
\hline $\mathrm{C}$ & -4.72421 & 0.63375 & -0.29495 \\
\hline $\mathrm{C}$ & -3.83053 & 1.49438 & -0.93935 \\
\hline $\mathrm{C}$ & -2.45486 & 1.26091 & -0.88967 \\
\hline $\mathrm{C}$ & -1.96050 & 0.16438 & -0.16949 \\
\hline $\mathrm{C}$ & -2.87485 & -0.72155 & 0.43120 \\
\hline $\mathrm{C}$ & -4.24530 & -0.49053 & 0.38487 \\
\hline $\mathrm{C}$ & -0.57956 & -0.35989 & -0.03786 \\
\hline $\mathrm{C}$ & -0.75892 & -1.88347 & 0.25815 \\
\hline $\mathrm{C}$ & -2.12436 & -1.87674 & 1.02940 \\
\hline $\mathrm{C}$ & 0.57951 & 0.35993 & -0.03793 \\
\hline $\mathrm{C}$ & 0.29988 & -2.54452 & 1.15392 \\
\hline $\mathrm{C}$ & -0.95612 & -2.69860 & -1.04124 \\
\hline $\mathrm{C}$ & 0.75895 & 1.88350 & 0.25812 \\
\hline $\mathrm{C}$ & 2.12425 & 1.87658 & 1.02960 \\
\hline $\mathrm{C}$ & 2.87479 & 0.72148 & 0.43126 \\
\hline $\mathrm{C}$ & 1.96044 & -0.16438 & -0.16954 \\
\hline $\mathrm{C}$ & 4.24524 & 0.49046 & 0.38494 \\
\hline $\mathrm{C}$ & 4.72415 & -0.63378 & -0.29495 \\
\hline $\mathrm{C}$ & 3.83047 & -1.49436 & -0.93941 \\
\hline $\mathrm{C}$ & 2.45481 & -1.26088 & -0.88975 \\
\hline $\mathrm{C}$ & -0.29986 & 2.54474 & 1.15371 \\
\hline $\mathrm{C}$ & 0.95648 & 2.69858 & -1.04126 \\
\hline $\mathrm{H}$ & -5.79309 & 0.82389 & -0.34555 \\
\hline $\mathrm{H}$ & -4.20916 & 2.34446 & -1.50102 \\
\hline $\mathrm{H}$ & -1.78327 & 1.91280 & -1.43602 \\
\hline $\mathrm{H}$ & -4.93784 & -1.18306 & 0.85795 \\
\hline $\mathrm{H}$ & -2.64876 & -2.83576 & 0.93906 \\
\hline $\mathrm{H}$ & -1.93992 & -1.70845 & 2.10049 \\
\hline $\mathrm{H}$ & -0.09077 & -3.50240 & 1.52044 \\
\hline $\mathrm{H}$ & 0.52558 & -1.91834 & 2.02410 \\
\hline $\mathrm{H}$ & 1.23879 & -2.75094 & 0.63912 \\
\hline $\mathrm{H}$ & -1.18346 & -3.74463 & -0.80018 \\
\hline $\mathrm{H}$ & -0.06235 & -2.68988 & -1.67190 \\
\hline $\mathrm{H}$ & -1.78509 & -2.29988 & -1.63565 \\
\hline $\mathrm{H}$ & 1.93957 & 1.70795 & 2.10060 \\
\hline $\mathrm{H}$ & 2.64868 & 2.83562 & 0.93966 \\
\hline $\mathrm{H}$ & 4.93777 & 1.18296 & 0.85809 \\
\hline $\mathrm{H}$ & 5.79302 & -0.82392 & -0.34555 \\
\hline $\mathrm{H}$ & 4.20911 & -2.34442 & -1.50110 \\
\hline $\mathrm{H}$ & 1.78323 & -1.91275 & -1.43614 \\
\hline $\mathrm{H}$ & 0.09062 & 3.50293 & 1.51961 \\
\hline $\mathrm{H}$ & -0.52519 & 1.91899 & 2.02430 \\
\hline $\mathrm{H}$ & -1.23895 & 2.75061 & 0.63902 \\
\hline $\mathrm{H}$ & 1.18426 & 3.74451 & -0.80021 \\
\hline
\end{tabular}




$\begin{array}{llll}\mathrm{H} & 0.06268 & 2.69023 & -1.67189 \\ \mathrm{H} & 1.78527 & 2.29952 & -1.63570\end{array}$

TABLE S7. Coordinate of the cis-1 at the B3LYP / 6-31G* level of theory.

\begin{tabular}{|c|c|c|c|}
\hline $\mathrm{C}$ & 3.55503 & -2.58760 & 0.42157 \\
\hline$C$ & 2.29385 & -2.79959 & 0.99134 \\
\hline $\mathrm{C}$ & 1.28470 & -1.84542 & 0.86783 \\
\hline $\mathrm{C}$ & 1.53097 & -0.66569 & 0.14892 \\
\hline $\mathrm{C}$ & 2.81440 & -0.44457 & -0.37871 \\
\hline $\mathrm{C}$ & 3.82241 & -1.39750 & -0.25911 \\
\hline $\mathrm{C}$ & 0.68220 & 0.54597 & -0.02270 \\
\hline $\mathrm{C}$ & 1.69378 & 1.70076 & -0.30131 \\
\hline $\mathrm{C}$ & 2.86948 & 0.92459 & -0.99124 \\
\hline $\mathrm{C}$ & -0.68220 & 0.54597 & 0.02270 \\
\hline $\mathrm{C}$ & -1.53097 & -0.66570 & -0.14891 \\
\hline $\mathrm{C}$ & -2.81441 & -0.44457 & 0.37871 \\
\hline $\mathrm{C}$ & -2.86948 & 0.92459 & 0.99124 \\
\hline $\mathrm{C}$ & -1.69378 & 1.70076 & 0.30131 \\
\hline $\mathrm{C}$ & -1.28470 & -1.84542 & -0.86783 \\
\hline $\mathrm{C}$ & -2.29385 & -2.79959 & -0.99134 \\
\hline $\mathrm{C}$ & -3.55503 & -2.58761 & -0.42157 \\
\hline $\mathrm{C}$ & -3.82241 & -1.39750 & 0.25911 \\
\hline $\mathrm{C}$ & -2.23987 & 2.30973 & -1.01221 \\
\hline $\mathrm{C}$ & 1.23349 & 2.80830 & -1.26080 \\
\hline $\mathrm{C}$ & 2.23987 & 2.30973 & 1.01221 \\
\hline $\mathrm{C}$ & -1.23350 & 2.80830 & 1.26080 \\
\hline $\mathrm{H}$ & 4.33284 & -3.33905 & 0.52952 \\
\hline $\mathrm{H}$ & 2.10138 & -3.71162 & 1.55059 \\
\hline $\mathrm{H}$ & 0.32083 & -2.01789 & 1.33379 \\
\hline $\mathrm{H}$ & 4.80975 & -1.21130 & -0.67577 \\
\hline $\mathrm{H}$ & 2.69296 & 0.87347 & -2.07587 \\
\hline $\mathrm{H}$ & 3.83012 & 1.43352 & -0.84654 \\
\hline $\mathrm{H}$ & -2.69296 & 0.87346 & 2.07587 \\
\hline $\mathrm{H}$ & -3.83013 & 1.43352 & 0.84654 \\
\hline $\mathrm{H}$ & -0.32083 & -2.01789 & -1.33378 \\
\hline $\mathrm{H}$ & -2.10138 & -3.71162 & -1.55059 \\
\hline $\mathrm{H}$ & -4.33284 & -3.33905 & -0.52952 \\
\hline $\mathrm{H}$ & -4.80975 & -1.21131 & 0.67576 \\
\hline $\mathrm{H}$ & -1.46010 & 2.81876 & -1.58266 \\
\hline $\mathrm{H}$ & -2.67241 & 1.53245 & -1.65128 \\
\hline H & -3.02714 & 3.04110 & -0.78951 \\
\hline
\end{tabular}




$\begin{array}{llcc}\mathrm{H} & 2.10364 & 3.40199 & -1.56886 \\ \mathrm{H} & 0.51824 & 3.50140 & -0.81576 \\ \mathrm{H} & 0.78317 & 2.38344 & -2.16433 \\ \mathrm{H} & 3.02714 & 3.04110 & 0.78950 \\ \mathrm{H} & 2.67241 & 1.53245 & 1.65128 \\ \mathrm{H} & 1.46010 & 2.81876 & 1.58266 \\ \mathrm{H} & -2.10365 & 3.40198 & 1.56886 \\ \mathrm{H} & -0.51824 & 3.50140 & 0.81576 \\ \mathrm{H} & -0.78318 & 2.38344 & 2.16433\end{array}$

TABLE S8. Coordinate of the trans-2 at the B3LYP / 6-31G* level of theory.
$\begin{array}{ll}0 & 1\end{array}$
$\begin{array}{llll}\text { C } & -4.747116 & 0.066940 & -0.516785\end{array}$
$\begin{array}{llll}\text { C } & -3.976929 & 1.036743 & -1.159409\end{array}$
$\begin{array}{llll}\text { C } & -2.584686 & 0.963455 & -1.099792\end{array}$
$\begin{array}{llll}\text { C } & -1.963715 & -0.067993 & -0.382278\end{array}$
$\begin{array}{llll}\text { C } & -2.769119 & -1.057800 & 0.211365\end{array}$
$\begin{array}{llll}\text { C } & -4.156967 & -0.999100 & 0.163925\end{array}$
$\begin{array}{llll}\text { C } & -0.532516 & -0.426636 & -0.248749\end{array}$
$\begin{array}{llll}\text { C } & -0.531876 & -1.961182 & 0.044937\end{array}$
$\begin{array}{llll}\text { C } & -1.891006 & -2.117081 & 0.812424\end{array}$
$\begin{array}{llll}\text { C } & 0.532471 & 0.426712 & -0.248947\end{array}$
$\begin{array}{llll}\text { C } & 0.594070 & -2.494553 & 0.943771\end{array}$
$\begin{array}{llll}\text { C } & -0.628464 & -2.791504 & -1.256561\end{array}$
$\begin{array}{llll}\mathrm{Br} & -6.654663 & 0.179214 & -0.608398\end{array}$
$\begin{array}{llll}\text { C } & 0.532028 & 1.961258 & 0.044846\end{array}$
$\begin{array}{llll}\text { C } & 1.890823 & 2.116531 & 0.813019\end{array}$
$\begin{array}{llll}\text { C } & 2.769073 & 1.057617 & 0.211487\end{array}$
$\begin{array}{llll}\text { C } & 1.963669 & 0.068085 & -0.382645\end{array}$
$\begin{array}{llll}\text { C } & 4.156906 & 0.998900 & 0.164185\end{array}$
$\begin{array}{llll}\text { C } & 4.747100 & -0.066895 & -0.516876\end{array}$
$\begin{array}{llll}\text { C } & 3.976944 & -1.036438 & -1.159882\end{array}$
$\begin{array}{llll}\text { C } & 2.584686 & -0.963135 & -1.100403\end{array}$
$\begin{array}{llll}\text { C } & -0.594116 & 2.495056 & 0.943130\end{array}$
$\begin{array}{llll}\text { C } & 0.629578 & 2.791534 & -1.256607\end{array}$
$\begin{array}{llll}\mathrm{Br} & 6.654648 & -0.179200 & -0.608307\end{array}$
$\begin{array}{llll}\mathrm{H} & -4.462067 & 1.830856 & -1.716370\end{array}$
$\begin{array}{llll}\mathrm{H} & -1.999329 & 1.696014 & -1.642395\end{array}$
$\begin{array}{llll}\mathrm{H} & -4.772705 & -1.762970 & 0.627823\end{array}$
$\begin{array}{llll}\mathrm{H} & -2.298935 & -3.130402 & 0.720856\end{array}$
$\mathrm{H} \quad-1.733444 \quad-1.925659 \quad 1.883636$
$\begin{array}{llll}\mathrm{H} & 0.317780 & -3.492477 & 1.306656\end{array}$ 


$\begin{array}{llll}\mathrm{H} & 0.741226 & -1.848541 & 1.816193 \\ \mathrm{H} & 1.552673 & -2.589890 & 0.432587 \\ \mathrm{H} & -0.732040 & -3.857422 & -1.018188 \\ \mathrm{H} & 0.260330 & -2.676178 & -1.883438 \\ \mathrm{H} & -1.495880 & -2.492798 & -1.854736 \\ \mathrm{H} & 1.732880 & 1.924240 & 1.884018 \\ \mathrm{H} & 2.298828 & 3.129929 & 0.722427 \\ \mathrm{H} & 4.772583 & 1.762573 & 0.628494 \\ \mathrm{H} & 4.462097 & -1.830383 & -1.717087 \\ \mathrm{H} & 1.999390 & -1.695541 & -1.643280 \\ \mathrm{H} & -0.317581 & 3.492844 & 1.306198 \\ \mathrm{H} & -0.741959 & 1.849091 & 1.815445 \\ \mathrm{H} & -1.552444 & 2.590866 & 0.431488 \\ \mathrm{H} & 0.733322 & 3.857407 & -1.018158 \\ \mathrm{H} & -0.258911 & 2.676407 & -1.884003 \\ \mathrm{H} & 1.497238 & 2.492584 & -1.854309\end{array}$

TABLE S9. Coordinate of the cis-2 at the B3LYP / 6-31G* level of theory.
$\begin{array}{ll}0 & 1\end{array}$
$\begin{array}{llll}\text { C } & 3.563705 & -2.372025 & -0.124847\end{array}$
C $\quad 2.360138 \quad-2.602951 \quad-0.795990$
$\begin{array}{llll}\text { C } & 1.349609 & -1.644409 & -0.751907\end{array}$
$\begin{array}{llll}\text { C } & 1.535767 & -0.460983 & -0.021317\end{array}$
$\begin{array}{llll}\text { C } & 2.774429 & -0.238586 & 0.603592\end{array}$
$\begin{array}{llll}\text { C } & 3.792908 & -1.186356 & 0.571487\end{array}$
$\begin{array}{llll}\text { C } & 0.678146 & 0.750732 & 0.078979\end{array}$
$\begin{array}{llll}\text { C } & 1.665634 & 1.905670 & 0.434631\end{array}$
$\begin{array}{llll}\text { C } & 2.784317 & 1.131668 & 1.215393\end{array}$
$\begin{array}{llll}\text { C } & -0.678146 & 0.750702 & -0.078995\end{array}$
$\begin{array}{llll}\text { C } & 1.131821 & 3.014328 & 1.354034\end{array}$
$\begin{array}{llll}\text { C } & 2.310440 & 2.512817 & -0.834000\end{array}$
$\mathrm{Br} \quad 4.940826 \quad-3.698654 \quad-0.197037$
$\begin{array}{llll}\text { C } & -1.665680 & 1.905670 & -0.434631\end{array}$
$\begin{array}{llll}\text { C } & -2.784348 & 1.131683 & -1.215378\end{array}$
$\begin{array}{llll}\text { C } & -2.774429 & -0.238617 & -0.603592\end{array}$
$\begin{array}{llll}\text { C } & -1.535767 & -0.460983 & 0.021286\end{array}$
$\begin{array}{llll}\text { C } & -3.792908 & -1.186356 & -0.571472\end{array}$
$\begin{array}{llll}\text { C } & -3.563705 & -2.372055 & 0.124832\end{array}$
$\begin{array}{llll}\text { C } & -2.360107 & -2.602966 & 0.795959\end{array}$
$\begin{array}{llll}\text { C } & -1.349594 & -1.644455 & 0.751892\end{array}$
$\begin{array}{llll}\text { C } & -1.131866 & 3.014343 & -1.354034\end{array}$
$\begin{array}{llll}\text { C } & -2.310425 & 2.512802 & 0.834000\end{array}$ 


$\begin{array}{lcrc}\mathrm{Br} & -4.940842 & -3.698654 & 0.197037 \\ \mathrm{H} & 2.223343 & -3.519196 & -1.359970 \\ \mathrm{H} & 0.428741 & -1.824402 & -1.295166 \\ \mathrm{H} & 4.746597 & -1.009659 & 1.058395 \\ \mathrm{H} & 3.754196 & 1.637497 & 1.144272 \\ \mathrm{H} & 2.524353 & 1.079651 & 2.282700 \\ \mathrm{H} & 1.974548 & 3.615891 & 1.717194 \\ \mathrm{H} & 0.623337 & 2.591995 & 2.227417 \\ \mathrm{H} & 0.443954 & 3.698654 & 0.855957 \\ \mathrm{H} & 3.077576 & 3.244888 & -0.552170 \\ \mathrm{H} & 1.575928 & 3.021164 & -1.462006 \\ \mathrm{H} & 2.791077 & 1.736053 & -1.438370 \\ \mathrm{H} & -2.524414 & 1.079666 & -2.282684 \\ \mathrm{H} & -3.754227 & 1.637497 & -1.144226 \\ \mathrm{H} & -4.746643 & -1.009659 & -1.058365 \\ \mathrm{H} & -2.223312 & -3.519211 & 1.359940 \\ \mathrm{H} & -0.428711 & -1.824463 & 1.295105 \\ \mathrm{H} & -1.974640 & 3.615921 & -1.717148 \\ \mathrm{H} & -0.623398 & 2.592041 & -2.227432 \\ \mathrm{H} & -0.443985 & 3.698654 & -0.855988 \\ \mathrm{H} & -3.077545 & 3.244873 & 0.552231 \\ \mathrm{H} & -1.575897 & 3.021133 & 1.462006 \\ \mathrm{H} & -2.791046 & 1.736084 & 1.438385\end{array}$

TABLE S10. Coordinate of the trans-8 at the B3LYP / 6-31G* level of theory.

\begin{tabular}{|c|c|c|c|}
\hline $\mathrm{CO}$ & -4.782745 & 0.291031 & -0.520203 \\
\hline $\mathrm{C} 0$ & -3.933000 & 1.208344 & -1.156235 \\
\hline $\mathrm{Co}$ & -2.544586 & 1.082153 & -1.101639 \\
\hline $\mathrm{C} 0$ & -1.966843 & 0.027542 & -0.382248 \\
\hline $\mathrm{CO}$ & -2.819717 & -0.921402 & 0.210587 \\
\hline $\mathrm{CO}$ & -4.201767 & -0.792847 & 0.155746 \\
\hline $\mathrm{CO}$ & -0.553558 & -0.398880 & -0.249710 \\
\hline $\mathrm{C} 0$ & -0.626785 & -1.931488 & 0.043915 \\
\hline $\mathrm{CO}$ & -1.992386 & -2.022476 & 0.809906 \\
\hline $\mathrm{C} 0$ & 0.553558 & 0.398895 & -0.249695 \\
\hline $\mathrm{C} 0$ & 0.626831 & 1.931503 & 0.043915 \\
\hline $\mathrm{CO}$ & 1.992432 & 2.022507 & 0.809814 \\
\hline $\mathrm{C}$ & 2.819717 & 0.921371 & 0.210556 \\
\hline $\mathrm{C} 0$ & 1.966827 & -0.027527 & -0.382278 \\
\hline $\mathrm{Co}$ & 4.201767 & 0.792770 & 0.155777 \\
\hline 4 & 4.782715 & -0.291153 & -0.52 \\
\hline
\end{tabular}




\begin{tabular}{|c|c|c|c|}
\hline & 53 & 05 & -1.1562 \\
\hline $\mathrm{CO}$ & .544540 & -1.082123 & -1.101715 \\
\hline & .282990 & 0.461900 & - 566071 \\
\hline & 0.473312 & -2.517273 & 41925 \\
\hline & -0.760788 & -2.756210 & -1.257462 \\
\hline & -0.47 & 34 & .941910 \\
\hline & 0.760834 & 2.756180 & -1.257523 \\
\hline & 6.282928 & -0.462112 & -0.566010 \\
\hline & -4.368652 & 2.027832 & -1.724014 \\
\hline & -1.927536 & 1.784576 & -1.649994 \\
\hline & -4.839630 & -.541550 & 0.622635 \\
\hline & -2.448044 & -3.015823 & 0.717026 \\
\hline & -1.824295 & -1.842850 & 1.881912 \\
\hline & 1.824387 & 1.843033 & 1.881866 \\
\hline & 2.448105 & 3.015854 & 0.716873 \\
\hline & 4.839676 & 1.541397 & 0.622711 \\
\hline $\mathrm{H} 0$ & 4.368546 & -2.027878 & -1.724075 \\
\hline 0 & 1.927444 & -1.784500 & -1.650100 \\
\hline 0 & -6.599869 & 0.992432 & -1.470459 \\
\hline Ho & -6.645050 & 1.042236 & 293747 \\
\hline 0 & -6.798355 & -0.504562 & -0.542297 \\
\hline 0 & 0.153366 & -3.503632 & 1.301529 \\
\hline HO & 0.646973 & -1.880325 & 816254 \\
\hline HO & 1.427658 & -2.649628 & 431030 \\
\hline HO & -0.918000 & -3.81 & 9669 \\
\hline & 0.134445 & -2.684570 & 36 \\
\hline HO & -1.611343 & -2.413788 & 491 \\
\hline & -0.153229 & 3.503662 & 544 \\
\hline & -0.646 & 1.88 & 010200 \\
\hline & -1.427567 & 2.64 & 0.430 \\
\hline HO & 0.918030 & 3.815979 & -1.019 \\
\hline HO & -0.134369 & 2.684479 & -1.881912 \\
\hline HO & 1.611389 & 2.413696 & -1.856537 \\
\hline HO & 6.599838 & -0.992508 & -1.470459 \\
\hline $\mathrm{H} 0$ & 58 & -1.042587 & .293732 \\
\hline $\mathrm{HO}$ & 798355 & 0.504333 & 5500 \\
\hline
\end{tabular}

TABLE S11. Coordinate of the trans-9 at the B3LYP / 6-31G* level of theory.
$\begin{array}{ll}0 & 1\end{array}$
$\begin{array}{llll}\text { C } & -4.751373 & -0.631042 & -0.505341\end{array}$
$\begin{array}{llll}\text { C } & -4.091293 & 0.443481 & -1.130905\end{array}$
$\begin{array}{llll}\text { C } & -2.705414 & 0.580612 & -1.076050\end{array}$ 


\begin{tabular}{|c|c|c|c|}
\hline & -1.934540 & 2814 & -0.36880 \\
\hline C & -2.588898 & -1.455124 & 0.211273 \\
\hline & -3.969376 & -1.593689 & 15863 \\
\hline & -0.466324 & -0.498550 & -0.23533 \\
\hline & -0.242264 & -2.018402 & 0.050934 \\
\hline & -1.566879 & -2.379333 & 0.808121 \\
\hline & 0.466354 & 0.498596 & -0.235413 \\
\hline & 0.242340 & 2.018494 & 0.050705 \\
\hline & 1.566910 & 2.379395 & 0.807938 \\
\hline & 2.588928 & 1.455154 & 0.211166 \\
\hline & 1.934555 & 0.352844 & -0.368881 \\
\hline & 3.969406 & 1.593674 & 0.158524 \\
\hline & 4.751373 & 0.630997 & -0.505402 \\
\hline c & 4.091293 & -0.443512 & -1.130920 \\
\hline & 2.705414 & -0.580627 & -1.076080 \\
\hline & -0.208374 & -2.843292 & -1.2 \\
\hline & 0.208603 & 2.843292 & -1.2 \\
\hline & 0.946091 & -2.384766 & 0.9 \\
\hline & -0.94 & 995 & 049 \\
\hline & -6.22 & -0.808334 & -0 . \\
\hline & 6.22 & 0.80 & -0 . \\
\hline C & -6.718216 & -2.010986 & 649 \\
\hline & -8 & -2 & 849 \\
\hline & -9.005981 & -1.251694 & -0.9 \\
\hline $\mathrm{C}$ & -8.561157 & -0.006943 & -0.424835 \\
\hline $\mathrm{C}$ & -7.155121 & 0.224960 & -0.242203 \\
\hline $\mathrm{C}$ & -9.485580 & 1.011795 & -0.067657 \\
\hline $\mathrm{C}$ & -9.057617 & 2.204605 & 0.467102 \\
\hline $\mathrm{C}$ & -7.676544 & 2.424194 & 0.680084 \\
\hline $\mathrm{C}$ & -6.753220 & 1.461075 & 0.337326 \\
\hline $\mathrm{C}$ & 6.718246 & 2.010880 & -1.096725 \\
\hline $\mathrm{C}$ & 8.102646 & 2.237640 & -1.260925 \\
\hline C & 9.006012 & 1.251541 & -0.943130 \\
\hline C & 8.561172 & 0.006821 & -0.424835 \\
\hline $\mathrm{C}$ & 7.155121 & -0.225052 & -0.242218 \\
\hline C & 9.485565 & -1.011932 & -0.067627 \\
\hline $\mathrm{C}$ & 9.057571 & -2.204727 & 0.467133 \\
\hline $\mathrm{C}$ & 7.676514 & -2.424271 & 0.680100 \\
\hline $\mathrm{C}$ & 6.753174 & -1.461151 & 0.337341 \\
\hline $\mathrm{H}$ & -4.673492 & 1.160156 & -1.703079 \\
\hline $\mathrm{H}$ & -2.234665 & 1.391998 & -1.618362 \\
\hline П & -4.455795 & -2.444321 & 0.6299 \\
\hline $\mathrm{H}$ & -1.820419 & -3.441132 & 0.704132 \\
\hline & -1.442703 & -2.179535 & 1.88 \\
\hline
\end{tabular}




$\begin{array}{cccc}\mathrm{H} & 1.442688 & 2.179657 & 1.882187 \\ \mathrm{H} & 1.820526 & 3.441193 & 0.703934 \\ \mathrm{H} & 4.455856 & 2.444336 & 0.629852 \\ \mathrm{H} & 2.234650 & -1.392014 & -1.618393 \\ \mathrm{H} & -0.150040 & -3.914734 & -1.027557 \\ \mathrm{H} & 0.652802 & -2.590012 & -1.882004 \\ \mathrm{H} & -1.111420 & -2.672562 & -1.852768 \\ \mathrm{H} & 0.150345 & 3.914734 & -1.027969 \\ \mathrm{H} & -0.652527 & 2.589996 & -1.882370 \\ \mathrm{H} & 1.111694 & 2.672424 & -1.852982 \\ \mathrm{H} & 0.822693 & -3.417480 & 1.303635 \\ \mathrm{H} & 0.986572 & -1.734161 & 1.834061 \\ \mathrm{H} & 1.911331 & -2.325012 & 0.449219 \\ \mathrm{H} & -0.822617 & 3.417740 & 1.303177 \\ \mathrm{H} & -0.986618 & 1.734497 & 1.833755 \\ \mathrm{H} & -1.911300 & 2.325211 & 0.448776 \\ \mathrm{H} & -.015305 & -2.787460 & -1.385590 \\ \mathrm{H} & -8.444900 & -3.191132 & -1.654388 \\ \mathrm{H} & -10.073120 & -1.411407 & -1.078171 \\ \mathrm{H} & -10.546158 & 0.824738 & -0.219818 \\ \mathrm{H} & -9.776474 & 2.973450 & 0.737335 \\ \mathrm{H} & -7.342194 & 3.357834 & 1.124680 \\ \mathrm{H} & -5.699615 & 1.637497 & 0.522583 \\ \mathrm{H} & 6.015381 & 2.787338 & -1.385696 \\ \mathrm{H} & 8.444992 & 3.190964 & -1.654480 \\ \mathrm{H} & 10.073181 & 1.411240 & -1.078171 \\ \mathrm{H} & 10.546143 & -0.824890 & -0.219788 \\ \mathrm{H} & 9.776413 & -2.973572 & 0.737427 \\ \mathrm{H} & 7.342102 & -3.357895 & 1.124741 \\ \mathrm{H} & 5.699570 & -1.637558 & 0.522583 \\ & & & \end{array}$

TABLE S12. Coordinate of the trans-10 at the B3LYP/ 6-31G (2d) level of theory.
$0 \quad 1$
$\begin{array}{llll}\text { C } & 4.77311 & 0.04527 & -0.09623\end{array}$
$\begin{array}{llll}\text { C } & 3.99072 & -0.93864 & -0.72995\end{array}$
C $\quad 2.60382 \quad-0.90024 \quad-0.67160$
$\begin{array}{llll}\text { C } & 1.95887 & 0.11915 & 0.04032\end{array}$
$\begin{array}{llll}\text { C } & 2.74285 & 1.12768 & 0.62990\end{array}$
$\begin{array}{llll}\text { C } & 4.12466 & 1.09651 & 0.58056\end{array}$
$\begin{array}{llll}\text { C } & 0.52329 & 0.44431 & 0.17132\end{array}$
$\begin{array}{llll}\text { C } & 0.48669 & 1.97780 & 0.46278\end{array}$
$\begin{array}{llll}\text { C } & 1.84183 & 2.16799 & 1.22652\end{array}$ 


\begin{tabular}{|c|c|c|c|}
\hline $\mathrm{C}$ & -0.52287 & -0.42979 & 0.17245 \\
\hline$C$ & -1.95851 & -0.10544 & 0.03936 \\
\hline $\mathrm{C}$ & -2.74248 & -1.11239 & 0.63168 \\
\hline C & -1.84154 & -2.15006 & 1.23288 \\
\hline $\mathrm{C}$ & -0.48614 & -1.96237 & 0.46910 \\
\hline $\mathrm{C}$ & -2.60349 & 0.91114 & -0.67658 \\
\hline $\mathrm{C}$ & -3.99042 & 0.94815 & -0.73692 \\
\hline $\mathrm{C}$ & -4.77272 & -0.03440 & -0.10111 \\
\hline $\mathrm{C}$ & -4.12416 & -1.08258 & 0.58038 \\
\hline $\mathrm{C}$ & -0.56149 & -2.79363 & -0.83151 \\
\hline $\mathrm{C}$ & 0.65141 & -2.46459 & 1.36850 \\
\hline $\mathrm{C}$ & 0.56253 & 2.80457 & -0.84067 \\
\hline $\mathrm{C}$ & -0.65137 & 2.48303 & 1.35983 \\
\hline $\mathrm{C}$ & 6.19567 & -0.00625 & -0.16576 \\
\hline $\mathrm{C}$ & -6.19532 & 0.01355 & -0.17250 \\
\hline $\mathrm{C}$ & 7.41238 & -0.05010 & -0.22374 \\
\hline $\mathrm{C}$ & -7.41227 & 0.05082 & $-0.2300^{7}$ \\
\hline $\mathrm{Si}$ & 9.24201 & -0.11698 & -0.31519 \\
\hline $\mathrm{C}$ & 9.94410 & -0.02347 & 1.42933 \\
\hline $\mathrm{C}$ & 9.85500 & 1.34279 & -1.33464 \\
\hline $\mathrm{C}$ & 9.74701 & -1.73567 & -1.13342 \\
\hline $\mathrm{Si}$ & -9.24293 & 0.09559 & -0.31433 \\
\hline $\mathrm{C}$ & -9.78961 & 1.84 & -0.7533 \\
\hline C & -9.93748 & -0.40240 & 1.363 \\
\hline $\mathrm{C}$ & -9.82163 & -1.11292 & -1.63756 \\
\hline $\mathrm{H}$ & 4.49027 & -1.72660 & -1.28653 \\
\hline $\mathrm{H}$ & 2.03219 & -1.64687 & -1.21089 \\
\hline $\mathrm{H}$ & 4.71929 & 1.88009 & 1.04370 \\
\hline $\mathrm{H}$ & 2.22635 & 3.19058 & 1.12875 \\
\hline $\mathrm{H}$ & 1.68963 & 1.98209 & 2.30015 \\
\hline $\mathrm{H}$ & -2.22570 & -3.17314 & 1.13891 \\
\hline $\mathrm{H}$ & -1.68996 & -1.95989 & 2.30585 \\
\hline $\mathrm{H}$ & -2.03181 & 1.65649 & -1.21760 \\
\hline $\mathrm{H}$ & -4.48985 & 1.73378 & -1.29691 \\
\hline $\mathrm{H}$ & -4.71874 & -1.86510 & 1.04538 \\
\hline $\mathrm{H}$ & -0.63550 & -3.86303 & -0.59447 \\
\hline $\mathrm{H}$ & 0.32186 & -2.65446 & -1.46185 \\
\hline $\mathrm{H}$ & -1.43907 & -2.51894 & -1.42759 \\
\hline $\mathrm{H}$ & 0.40014 & -3.46850 & 1.73556 \\
\hline $\mathrm{H}$ & 0.78249 & -1.81289 & 2.23995 \\
\hline $\mathrm{H}$ & 1.61290 & -2.53817 & 0.85830 \\
\hline $\mathrm{H}$ & 0.63646 & 3.87479 & -0.60734 \\
\hline $\mathrm{H}$ & -0.32063 & 2.66320 & -1.47080 \\
\hline $\mathrm{H}$ & 1.44030 & 2.52782 & -1.43554 \\
\hline
\end{tabular}




$\begin{array}{llll}\mathrm{H} & -0.40065 & 3.48839 & 1.72327 \\ \mathrm{H} & -0.78262 & 1.83450 & 2.23361 \\ \mathrm{H} & -1.61264 & 2.55433 & 0.84885 \\ \mathrm{H} & 11.04080 & -0.06444 & 1.41050 \\ \mathrm{H} & 9.58888 & -0.85561 & 2.04838 \\ \mathrm{H} & 9.65356 & 0.90975 & 1.92607 \\ \mathrm{H} & 10.95018 & 1.33505 & -1.40857 \\ \mathrm{H} & 9.55778 & 2.29701 & -0.88386 \\ \mathrm{H} & 9.45112 & 1.31543 & -2.35349 \\ \mathrm{H} & 10.83923 & -1.80975 & -1.21309 \\ \mathrm{H} & 9.33267 & -1.81644 & -2.14529 \\ \mathrm{H} & 9.39505 & -2.60033 & -0.55853 \\ \mathrm{H} & -10.88383 & 1.90601 & -0.81136 \\ \mathrm{H} & -9.38563 & 2.15403 & -1.72388 \\ \mathrm{H} & -9.45250 & 2.56787 & -0.00330 \\ \mathrm{H} & -11.03499 & -0.38992 & 1.35255 \\ \mathrm{H} & -9.60338 & 0.28173 & 2.15229 \\ \mathrm{H} & -9.61825 & -1.41372 & 1.64175 \\ \mathrm{H} & -10.91675 & -1.11539 & -1.71232 \\ \mathrm{H} & -9.50011 & -2.13640 & -1.41156 \\ \mathrm{H} & -9.42024 & -0.84740 & -2.62265\end{array}$

(a)

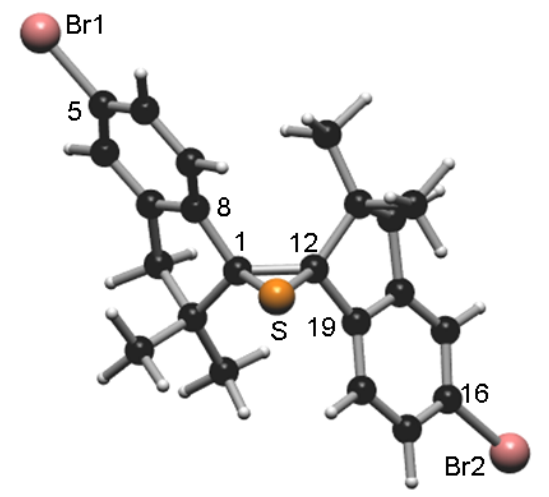

(b)

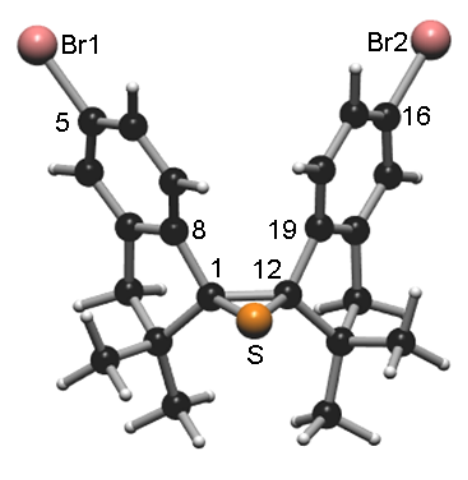

FIGURE S32. Optimized stuctures of trans-6 (a) and cis-6 (b) at DFT // B3LYP/ 6-31G* theory. Selected bond lengths ( $\AA$ ) and angles ( ${ }^{\circ}$ ) of trans-6 (a); Cl-C12 1.535, Cl-S 1.854, C12-S 1.854, C5-Br1 1.914, C16-Br2 1.914, C8-C1-S 113.4, C19-C12-S 113.4, C8-C1-C12-C19-153.9. Selected bond lengths ( $\AA$ ) and angles ( ${ }^{\circ}$ ) of cis-6 (b); Cl-C12 1.555, Cl-S 1.845, C12-S 1.841, C5-Br1 1.913, C16-Br2 1.914, C8-C1-S 115.6, C19-C12-S 123.5, C8-C1-C12-C19-9.6. 


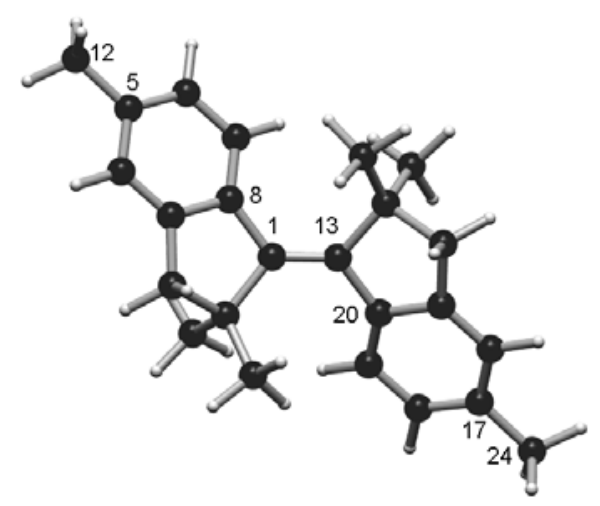

FIGURE S33. Optimized structure of trans-8 at the B3LYP / 6-31G* level of theory. Selected bond lengths $(\AA)$ and angles $\left({ }^{\circ}\right)$ of trans-8; C1-C13 1.365, C5-C12 1.511,C21-C28 1.511,C8-C1-C13-C20-167.1.

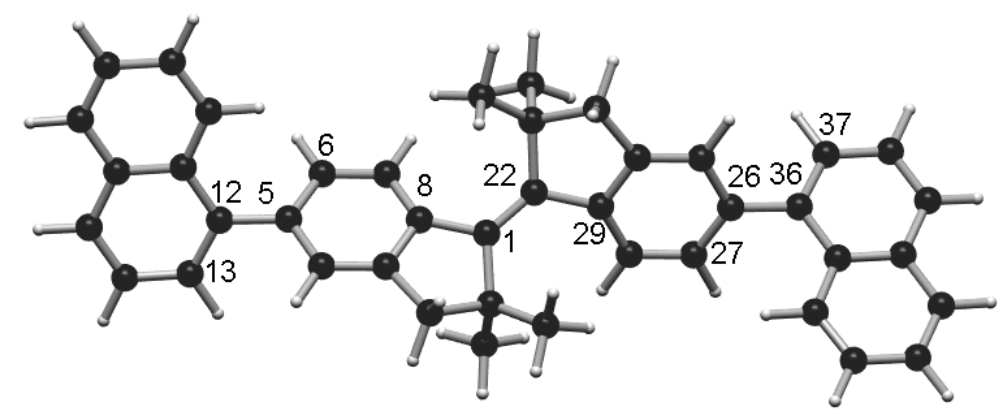

FIGURE S34 Optimized structure of trans-9 at the B3LYP / 6-31G* level of theory. Selected bond lengths $(\AA)$ and angles $\left({ }^{9}\right)$ of trans-9; C1-C22 1.365, C5-C12 1.489, C26-C36 1.489, C8-C1-C22-C29-167.0, C6-C5-C12-C13-124.5, C27-C26-C36-C37-124.5.

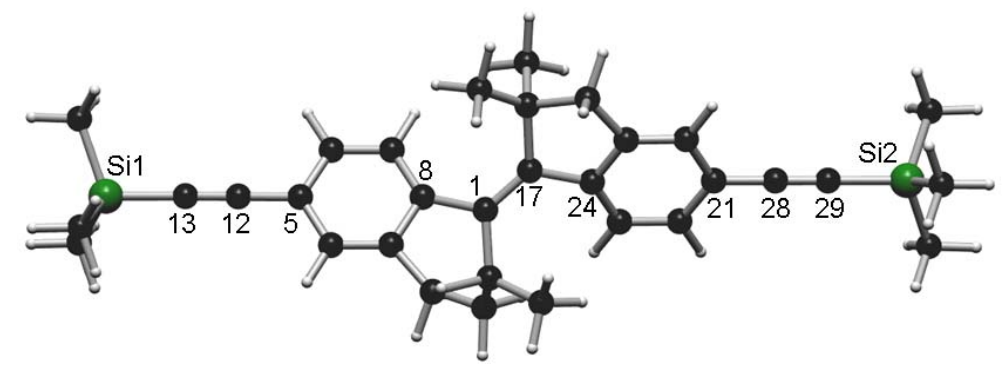

FIGURE S35. Optimized structure of trans-10 at the B3LYP / 6-31G (2d) level of theory. Selected bond lengths $(\AA)$ and angles ( $\left(^{9}\right)$ of trans-10; C1-C17 1.363, C5-C12 1.425, C21-C28 1.425, C13-Si1 1.833, C29-Si2 1.833, C12-C13 1.219, C28-C29 1.219, C8-C1-C17-C24 -167.1, C5-C12-C13-Si1-31.2,C21-C28-C29-Si2 176.1. 
(a)

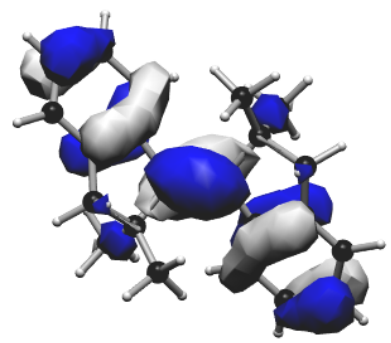

(c)

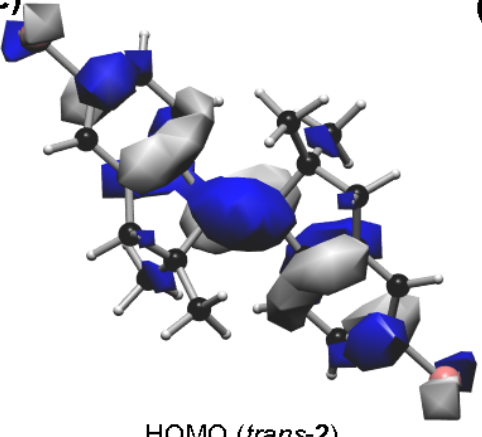

(b)

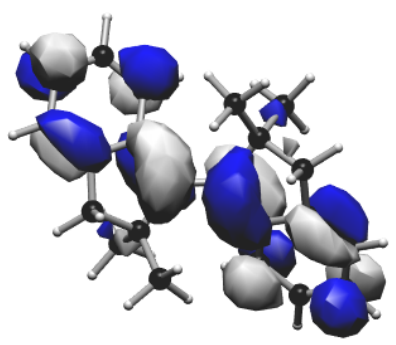

(d)

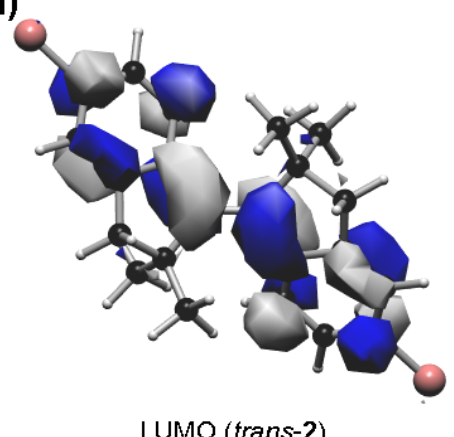

FIGURE S36. Frontier orbitals of the optimized trans-1 and 2 at B3LYP / 6-311G** level of theory. (a) HOMO of trans-1: $-5.48 \mathrm{eV}$. (b) HOMO of trans-2:-5.71 eV. (c)LUMO of trans-1:-1.44 eV. (d)LUMO of trans-2:-1.82 eV.

(a)

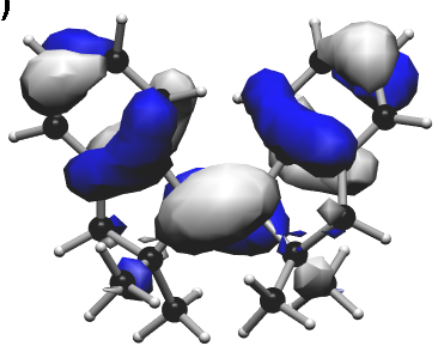

(c)

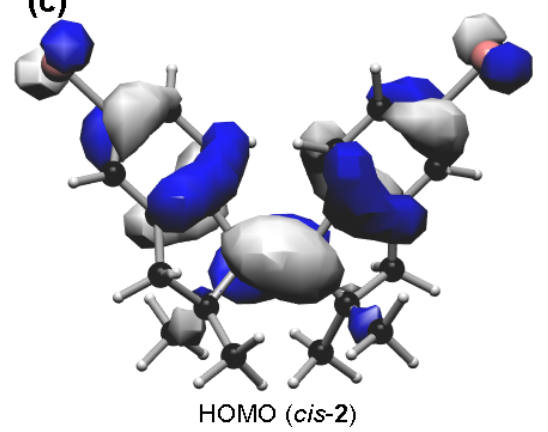

(b)

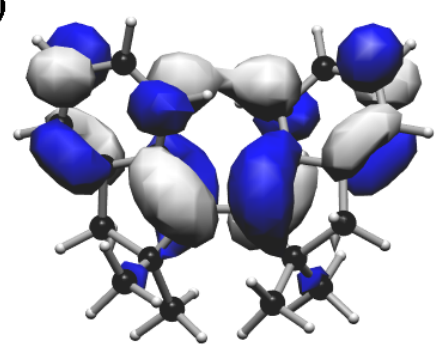

(d)

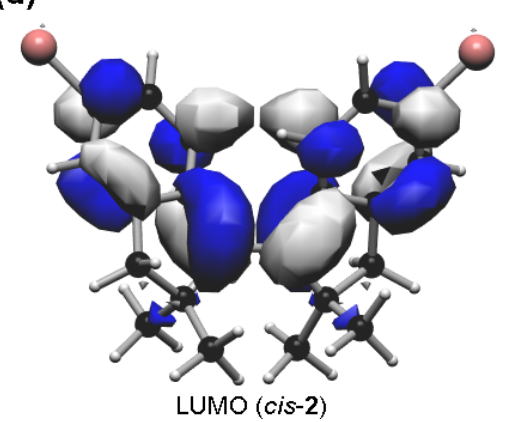

FIGURE S37. Frontier orbitals of the optimized cis-1 and 2 at B3LYP $/ 6-311 \mathrm{G}^{* *}$ level of theory. (a) $\mathrm{HOMO}$ of cis-1: $-5.63 \mathrm{eV}$. (b) $\mathrm{HOMO}$ of cis-2:-5.71 eV. (c)LUMO of cis-1:-1.85 eV. (d)LUMO of cis-2:-1.82 eV. 


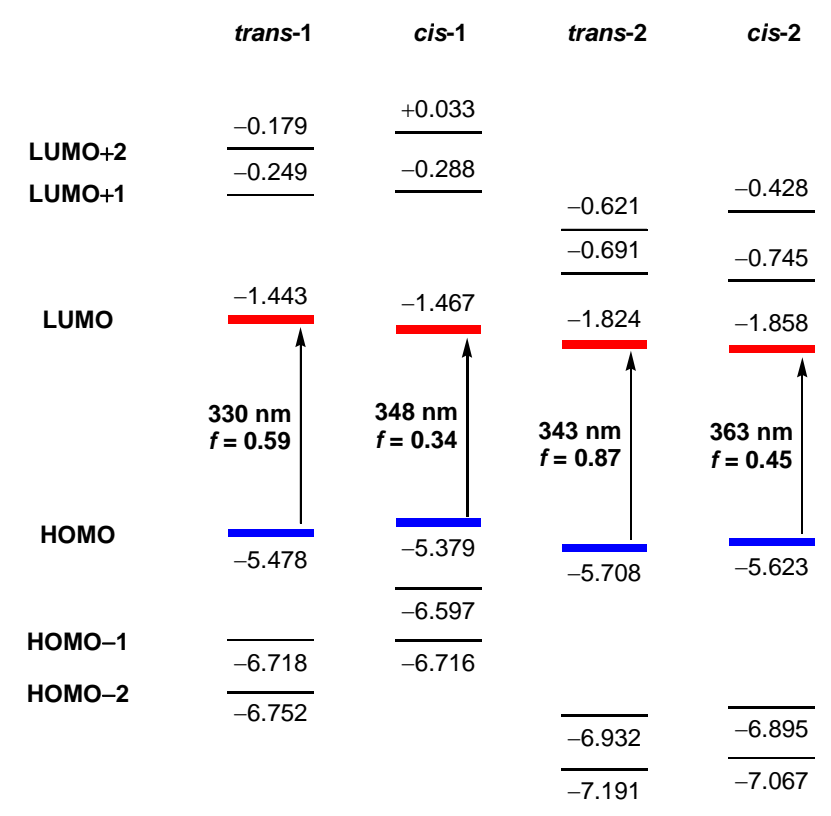

FIGURE S38. MO levels (eV) obtained by the DFT // B3LYP 6-311+G** level calculations. Energy transitions and the oscillator strengths for the most importantHOMO-LUMObands.
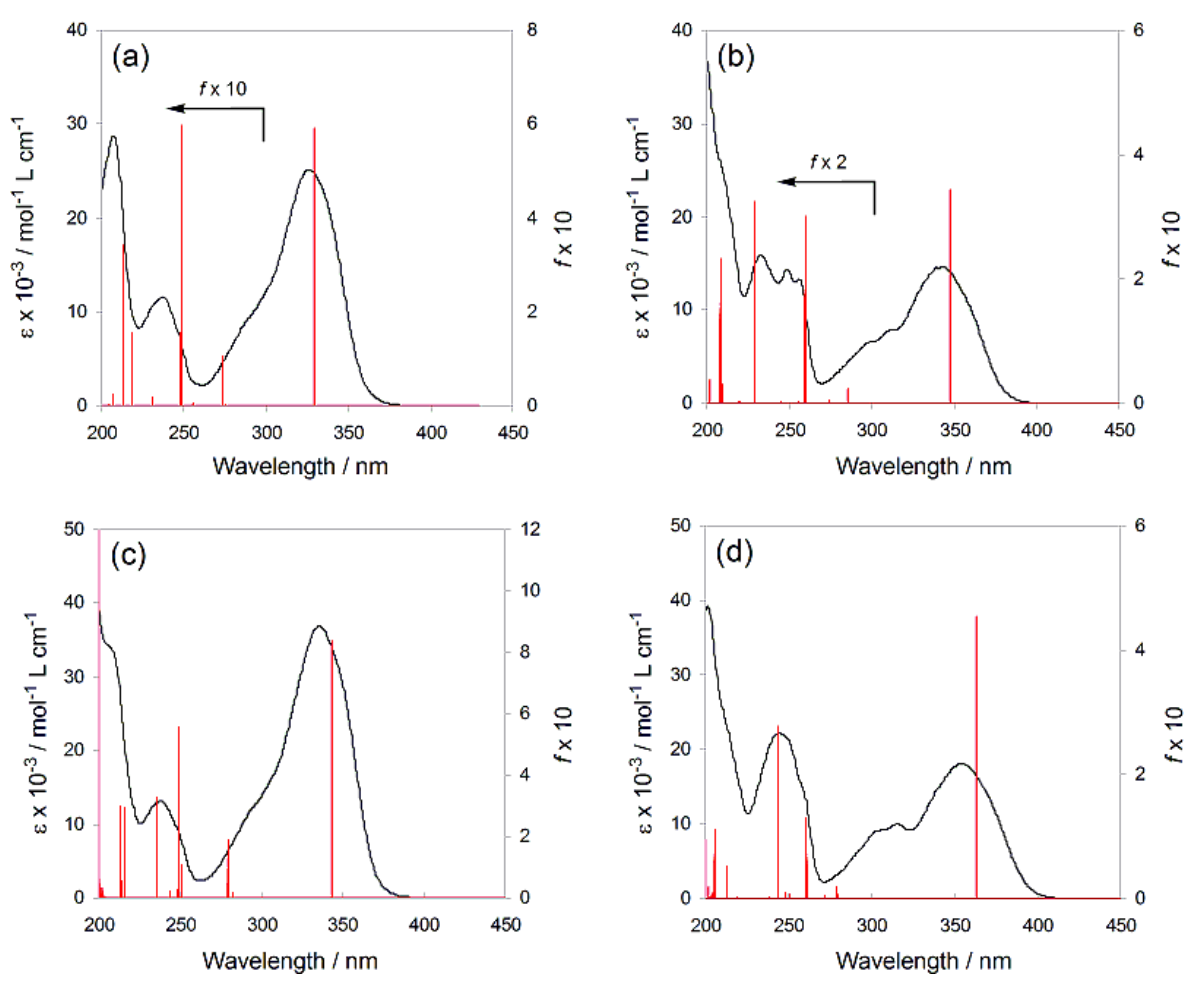

FIGURE S39. Calculated (red bar) oscillator strengths (f) of trans-1 (a), trans-2 (b), cis-1 (c) and cis-2 (d) at TDDFT // B3LYP/ 6-31G* level of theory with experimental one, respectively. 

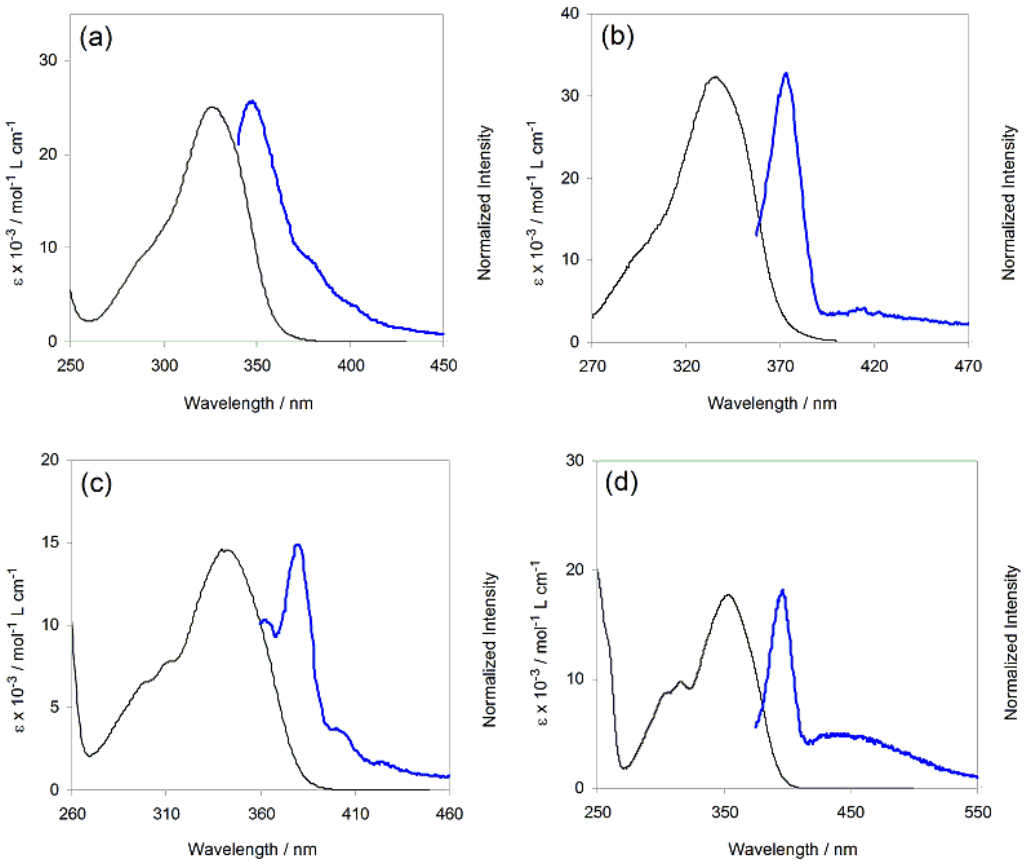

FIGURE S40. Electronic spectra of trans-1 (a, absorption: black, fluorescence: blue, $\lambda_{\mathrm{ex}} 315 \mathrm{~nm}$ ), trans-2 (b, absorption: black, fluorescence: blue, $\lambda_{\mathrm{ex}}$ $336 \mathrm{~nm}$ ), cis-1 (c, absorption: black, emission: blue, $\lambda_{\mathrm{ex}} 341 \mathrm{~nm}$ ), and cis-2 (d, absoption: black, emission: blue, $\lambda_{\mathrm{ex}} / 354 \mathrm{~nm}$ ) at $1 \times 10^{-5} \mathrm{~mol} / \mathrm{LinCH}_{3} \mathrm{CN}$ at $23^{\circ} \mathrm{C}$

TABLE S13. UV-vis and fluorescent data of stiff-stilbenes in $\mathrm{CH}_{3} \mathrm{CN}$ (concentration $1.0 \times 10^{-5} \mathrm{~mol} / \mathrm{L}$ )at $23^{\circ} \mathrm{C}$.

\begin{tabular}{|c|c|c|c|c|c|c|c|}
\hline & \multicolumn{4}{|c|}{ Absorption } & \multicolumn{2}{|c|}{ Emission } & \multirow{2}{*}{$\begin{array}{c}\text { Stokes } \\
\text { shift / nm }\end{array}$} \\
\hline & obsd. $\lambda$ & $\max \left(\mathrm{nm}^{\mathrm{a}}, \varepsilon^{\mathrm{b}}\right)$ & calcd. 1 & $x^{(n m, f)^{c}}$ & $\lambda / \mathrm{nm}$ & $\Phi_{f}{ }^{d}$ & \\
\hline trans-1 & 326 & 25100 & 329.5 & 0.590 & 348 & $<0.001$ & 12 \\
\hline trans-2 & 336 & 36900 & 343.2 & 0.837 & 374 & $<0.001$ & 34 \\
\hline cis-1 & 340 & 14600 & 347.6 & 0.344 & 363,380 & $<0.001$ & 44 \\
\hline cis-2 & 355 & 18100 & 363.2 & 0.453 & 397 & $<0.001$ & 42 \\
\hline
\end{tabular}

${ }^{a}$ Wavelengths of maximum absorptions in the stilbene band region. ${ }^{b}$ Molar extinction coefficient of the absorption at the longest wavelength. ${ }^{\circ} \mathrm{TDDFT}$ (TD / B3LYP / 6-31G* level) calculations were carried out using optimized structures at the B3LYP / 6-31G* level of theory. ${ }^{\mathrm{d}}$ Fluorescence quantum yield determined relative to indol. 
TABLES14 Selected data ofUV calculations by TDDFT method atB3LYP/6-31G* level of theory for trans-1. ${ }^{\text {a }}$

\begin{tabular}{|c|c|c|c|c|}
\hline State & Energy (eV) & $\lambda / \mathrm{nm}$ & Osc. & Configuration \\
\hline 1 & 3.7688 & 328.98 & 0.5903 & HOMO --> LUMO \\
\hline 3 & 4.5395 & 273.12 & 0.0106 & HOMO-2 --> LUMO; HOMO --> LUMO+2 \\
\hline 5 & 5.0072 & 247.61 & 0.0598 & $\begin{array}{l}\text { HOMO-3 --> LUMO+2; HOMO-2 --> LUMO; } \\
\text { HOMO --> LUMO+2 }\end{array}$ \\
\hline 6 & 5.0104 & 247.45 & 0.0156 & $\begin{array}{l}\text { HOMO-3 --> LUMO; HOMO-3 --> LUMO+2; } \\
\text { HOMO-1 --> LUMO; HOMO --> LUMO+1; } \\
\text { HOMO --> LUMO+3 }\end{array}$ \\
\hline 8 & 5.7016 & 217.46 & 0.0155 & $\begin{array}{l}\text { HOMO-5 --> LUMO; HOMO-4 --> LUMO; } \\
\text { HOMO --> LUMO+4 }\end{array}$ \\
\hline 9 & 5.8507 & 211.91 & 0.0341 & HOMO-5 --> LUMO; HOMO --> LUMO+4 \\
\hline
\end{tabular}

a). Calculations were carried out for the lowest 20 excited states. Excited states of $f<0.01$ are not listed.

TABLE S15. Selected data of UV calculations by TDDFT method at B3LYP/ 6-31G* for cis-1. ${ }^{\text {a }}$

\begin{tabular}{|c|c|c|c|c|}
\hline State & Energy (eV) & $\lambda / \mathrm{nm}$ & Osc. & Configuration \\
\hline 1 & 3.5669 & 347.60 & 0.3442 & HOMO --> LUMO \\
\hline 2 & 4.3359 & 285.95 & 0.0120 & HOMO-1 --> LUMO; HOMO --> LUMO+1 \\
\hline 4 & 4.7744 & 259.69 & 0.1502 & HOMO-1 --> LUMO; HOMO --> LUMO+1; \\
\hline 7 & 5.4089 & 229.22 & 0.1628 & $\begin{array}{l}\text { HOMO-3 --> LUMO; HOMO-2 --> LUMO+1; } \\
\text { HOMO-1 --> LUMO+2; HOMO-1 --> LUMO+3; } \\
\text { HOMO --> LUMO+3 }\end{array}$ \\
\hline 9 & 5.9156 & 209.59 & 0.0154 & $\begin{array}{l}\text { HOMO-5 --> LUMO; HOMO-4 --> LUMO; } \\
\text { HOMO --> LUMO+4 }\end{array}$ \\
\hline 10 & 5.9491 & 208.41 & 0.1166 & $\begin{array}{l}\text { HOMO-2 --> LUMO+2; HOMO-2 --> LUMO+3 } \\
\text { HOMO-1 --> LUMO+1; HOMO --> LUMO+4 }\end{array}$ \\
\hline
\end{tabular}

a). Calculations were carried out for the lowest 20 excited states. Excited states of $f<0.01$ are not listed.

TABLE S16. Selected data of UV calculations by TDDFT method at B3LYP / 6-31G* for trans-2.

\begin{tabular}{|c|c|c|c|c|}
\hline State & Energy (eV) & $\lambda / \mathrm{nm}$ & Osc. & Configuration \\
\hline 1 & 3.6123 & 343.23 & 0.8359 & HOMO --> LUMO \\
\hline 3 & 4.4384 & 279.34 & 0.0189 & HOMO-2 --> LUMO; HOMO --> LUMO+2 \\
\hline 5 & 4.9425 & 250.86 & 0.0111 & $\begin{array}{l}\text { HOMO-3 --> LUMO; HOMO-1 --> LUMO; } \\
\text { HOMO-1 --> LUMO+2; HOMO-1 --> LUMO+1; } \\
\text { HOMO --> LUMO+3; HOMO --> LUMO+5 }\end{array}$ \\
\hline 6 & 4.9687 & 249.53 & 0.0558 & $\begin{array}{l}\text { HOMO-2 --> LUMO; HOMO-1 --> LUMO+1; } \\
\text { HOMO --> LUMO+2 }\end{array}$ \\
\hline 10 & 5.2643 & 235.52 & 0.0331 & HOMO-5 --> LUMO; HOMO-4 --> LUMO+3 \\
\hline 13 & 5.7381 & 216.07 & 0.0294 & $\begin{array}{l}\text { HOMO-7 --> LUMO; HOMO-5 --> LUMO+2; } \\
\text { HOMO-3 --> LUMO+3; HOMO-2 --> LUMO; } \\
\text { HOMO-2 --> LUMO+2; HOMO-1 --> LUMO+1 }\end{array}$ \\
\hline 15 & 5.8075 & 213.49 & 0.0298 & HOMO-7 --> LUMO; HOMO --> LUMO+6 \\
\hline
\end{tabular}

a). Calculations were carried out for the lowest 20 excited states. Excited states of $f<0.01$ are not listed. 
TABLE S17. Selected data of UV calculations by TDDFT method at B3LYP/6-31G* for cis-2. ${ }^{\mathrm{a}}$

\begin{tabular}{|c|c|c|c|c|}
\hline State & Energy (eV) & $\lambda / \mathrm{nm}$ & Osc. & Configuration \\
\hline 1 & 3.4139 & 363.17 & 0.4530 & HOMO --> LUMO \\
\hline 2 & 4.2353 & 292.74 & 0.0533 & HOMO-2 --> LUMO; HOMO --> LUMO+1 \\
\hline 3 & 4.4408 & 279.19 & 0.0192 & $\begin{array}{l}\text { HOMO-3 --> LUMO; HOMO-1 --> LUMO; } \\
\text { HOMO --> LUMO+2; HOMO --> LUMO+3 }\end{array}$ \\
\hline 5 & 4.7537 & 260.82 & 0.1286 & $\begin{array}{l}\text { HOMO-2 --> LUMO; HOMO-1 --> LUMO+2; } \\
\text { HOMO --> LUMO+1 }\end{array}$ \\
\hline 8 & 4.9903 & 248.45 & 0.0103 & $\begin{array}{l}\text { HOMO-3 --> LUMO; HOMO-1 --> LUMO; } \\
\text { HOMO-1 --> LUMO+1; HOMO --> LUMO+2; } \\
\text { HOMO --> LUMO+3; HOMO --> LUMO+5 }\end{array}$ \\
\hline 9 & 5.0779 & 244.16 & 0.2780 & $\begin{array}{l}\text { HOMO-3 --> LUMO; HOMO-3 --> LUMO+1; } \\
\text { HOMO-1 --> LUMO; HOMO --> LUMO+2; } \\
\text { HOMO --> LUMO+4 }\end{array}$ \\
\hline 14 & 5.8164 & 213.16 & 0.0508 & $\begin{array}{l}\text { HOMO-4 --> LUMO+1; HOMO-3 --> LUMO+3; } \\
\text { HOMO-2 --> LUMO+1; HOMO-1 --> LUMO+2; } \\
\text { HOMO-1 --> LUMO+3 }\end{array}$ \\
\hline 15 & 5.8372 & 212.40 & 0.0132 & HOMO-7 --> LUMO; HOMO --> LUMO+6 \\
\hline 16 & 6.0241 & 205.81 & 0.1115 & $\begin{array}{l}\text { HOMO-7 --> LUMO; HOMO-3 --> LUMO+2; } \\
\text { HOMO-3 --> LUMO+3; HOMO-2 --> LUMO+1; } \\
\text { HOMO-2 --> LUMO+4; HOMO-1 --> LUMO+2; } \\
\text { HOMO --> LUMO+6 }\end{array}$ \\
\hline 22 & 6.1544 & 201.46 & 0.0181 & $\begin{array}{l}\text { HOMO-8 --> LUMO; HOMO-3 --> LUMO+1; } \\
\text { HOMO-3 --> LUMO+4; HOMO-2 --> LUMO+3; } \\
\text { HOMO-2 --> LUMO+5; HOMO-1 --> LUMO+4 }\end{array}$ \\
\hline
\end{tabular}

a). Calculations were carried out for the lowest 30 excited states. Excited states of $f<0.01$ are not listed.

\section{Reference and notes}

(1) (a) Lenoir, D.; Lemmen, P. Chem. Ber. 1980, 113, 3112. (b) Lenoir, D.; Lemmen, P. Chem. Ber. 1984, 117, 2300.

(2) Frisch, M. J.; Trucks, G. W.; Schlegel, H. B.; Scuseria, G. E.; Robb, M. A.; Cheeseman, J. R.; Montgomery, J.

A., Jr.; Vreven, T.; Kudin, K. N.; Burant, J. C.; Millam, J. M.; Iyengar, S. S.; Tomasi, J.; Barone, V.; Mennucci,

B.; Cossi, M.; Scalmani, G; Rega, N.; Petersson, G. A.; Nakatsuji, H.; Hada, M.; Ehara, M.; Toyota, K.; Fukuda, R.; Hasegawa, J.; Ishida, M.; Nakajima. T.; Honda, Y.; Kitao, O.; Nakai, H.; Klene, M.; Li, X.; knox, J. E.;

Hratchian, H. P.; Cross, J. B.; Bakken, V.; Adamo, C.; Jaramillo, J.; Gomperts, R.; Stratmann, R. E.; Yazyev, O.;

Austin, A. J.; Cammi, R.; Pomelli, C.; Ochterski, J. W.; Ayala, P. Y.; Morokuma, K.; Voth, G. A.; Salvador, P.; 
Dannenberg, J. J.; Zakrzewski, V. G.; Dapprich, S.; Daniels, A. D.; Strain, M. C.; Farkas, O.; Malick, D. K.;

Rabuck, A. D.; Raghavachari, K.; Foresman, J. B.; Ortiz, J. V.; Cui, Q.; Baboul, A. G.; Clifford, S.; Cioslowski, J.; Stefanov, B. B.; Liu, G; Liashenko, A.; Piskorz, P.; komaromi, I.; Martin, R. L.; Fox, D. J.; Keith, T.;

Al-Lahm, M. A.; Peng, C. Y.; Nanayakkara, A.; Challacombe, M.; Gill, P. M. W.; Johnson, B.; Chen, W.; Wong, M. W.; Gonzales, C.; Pople, J. A.; Gaussian 03, revision C.02; Gaussian, Inc.: Wallingford, CT, 2004.

(3) Becke, D. J. Chem. Phys. 1993, 5648.

(4) Lee, C.; Yang, W.; Parr, R. G. Phys. Rev. B. 1988, 37, 785.

(5) Miehlich, B.; Savin, A.; Stoll, H.; Preuss, H. Chem. Phys. Lett. 1989, 157, 200.

(6) Sheldrick, G. M. SHELXL97, Program for the Refinement of Crystal Structures, University of Göttingen, Germany, 1997.

(7) For the rates of isomerization of azobenzene, see: Yamashita, S.; Ono, H.; Toyama, O. Bull Chem. Soc. Jpn. 1962, 35, 1849-1853. 